\title{
Isolation of Bacteria with Potential Plant-Promoting Traits and Optimization of Their Growth Conditions
}

\author{
Mohammad Yaghoubi Khanghahi ${ }^{1} \cdot$ Sabrina Strafella ${ }^{1} \cdot$ Ignazio Allegretta $^{1} \cdot$ Carmine Crecchio $^{1}$ (i)
}

Received: 14 May 2020 / Accepted: 20 November 2020 / Published online: 23 December 2020

(c) The Author(s) 2020

\begin{abstract}
This research aimed at investigating the isolation and identification of bacterial strains with biological nitrogen-fixing capability and phosphate, potassium, and zinc solubilization activities from a durum wheat field under two different tillage practices including 10 years of conventional tillage (CT) and no-tillage (NT) practices. Attempts were also extended to estimate their relative abundances in the soil as well as to develop accurate mathematical models in determining the effect of different temperatures, $\mathrm{NaCl}$ concentrations and $\mathrm{pH}$ on the growth, and activity of selected isolates. Twelve effective bacterial strains, including Pseudomonas, Acinetobacter, and Comamonas genera, were identified with a great potential to solubilize the insoluble forms of phosphate (from 11.1 to $115.5 \mathrm{mg} \mathrm{l}^{-1}$ at $\mathrm{pH}$ 8), potassium (from 32.2 to $35.6 \mathrm{mg}^{-1}$ at $\mathrm{pH}$ 7), and zinc (from 1.11 to $389.90 \mathrm{mg} \mathrm{l}^{-1}$ at $\mathrm{pH}$ 9) as well as to fix $\mathrm{N}_{2}$ gas (from 19.9 to $25.2 \mathrm{mg} \mathrm{l}^{-1}$ ). To our knowledge, this is the first report of the ability of Comamonas testosteroni and Acinetobacter pittii to fix nitrogen and to solubilize insoluble potassium compound, respectively. Three families, Moraxellaceae, Pseudomonadaceae, and Comamonadaceae, showed a higher percentage of abundance in the NT samples as compared to the CT, but only significant difference was observed in the relative abundance of Pseudomonadaceae $(P<0.01)$. These strains could be definitively recommended as inoculants to promote plant growth in the wide ranges of $\mathrm{pH}$, salinity levels (with maximum growth and complete inhibition of growth from $0.67-0.92 \%$ to $3.5-9.3 \% \mathrm{NaCl}$, respectively), and temperatures $\left(2.1-45.1{ }^{\circ} \mathrm{C}\right)$.
\end{abstract}

\section{Introduction}

Wheat cultivation is the main farmers' income source in the Mediterranean area. This plant requires about $15-30 \mathrm{~kg}$ nitrogen $(\mathrm{N}), 3-5 \mathrm{~kg}$ phosphorus $(\mathrm{P}), 3-6 \mathrm{~kg}$ potassium $(\mathrm{K})$, and $0.03-0.06 \mathrm{~kg}$ Zinc $(\mathrm{Zn})$ per ton of grain yield [1, 2]. Since total grain production of durum wheat (Triticum durum Desf.) in Italy, one of the leaders in the world is around 42.46 million tons in 2018 [3], it can be easily estimated how many megatons of these nutrients are needed for wheat cultivation as an annual removal from soil. On the other hand, much more chemical fertilizers are generally applied to supply essential nutrients to the soil-plant system throughout the world, because some elements once applied are not easily available to the plant [4]. For example, less than half (10-40\%) of the applied nitrogen in the field is effectively absorbed by plants, and $60-90 \%$ of chemical

Carmine Crecchio

carmine.crecchio@uniba.it

1 Department of Soil, Plant and Food Sciences, University of Bari Aldo Moro, Via Amendola 165/A, 70126 Bari, Italy
$\mathrm{N}$ fertilizers are generally lost by nitrate leaching or ammonia volatilization [5]. Also, $\mathrm{P}$ absorption by the wheat plant is only about $20 \%$ of the chemical fertilizer applied at the first year [2]. In addition, some elements dissolve relatively slowly in soil, taking too much time to supply adequate amounts required for plant growth [4]. Therefore, farmers usually apply huge amounts of chemical fertilizers, which can result in negative impact on human health and the environment such as soil pollution and/or greenhouse-gas generation [6]. This problem is associated with costs and availability of chemical fertilizers which are real issues of today's agriculture [7].

Therefore, interest has grown in eco-friendly and costeffective agro-technologies to enhance crop production and reduce the chemical fertilizers input while minimizing negative effects on the environment and food [7, 8]. Soil microbial composition and abundance, as a component of soil ecosystem, play an important role in nutrient availability in soil and nutrient status in the plant [9]. The use of microbial inoculants or naturally occurring plant growth-promoting bacteria (PGPB) in sustainable agriculture is becoming a more widely accepted practice in many parts of the world 
$[10,11]$. PGPB promote plant growth usually by direct and indirect mechanisms including biological nitrogen fixation, organic matter mineralization, phytohormones production, e.g., auxins, cytokinins, and gibberellins, biological control against soil borne pathogens, cellulose degradation, starch hydrolysis, production of hydrogen cyanide, antibiotic, siderophore, and certain volatile organic compounds [10]. However, the PGPB efficiency is strongly affected by environmental factors such as salinity, $\mathrm{pH}$, and temperature due to changing their survival, growth, and activity to stressful conditions $[6,11]$. The majority of credible group of PGPB belongs to genera Acinetobacter, Azadirachta, Azotobacter, Azospirillium, Bacillus, Pantoea, Pseudomonas, Rahnella, Rhizobium, Serratia, and Streptomyces sp. [6, 11-13]. In this regard, Bakhshandeh et al. [6] isolated several bacterial strains with phosphate solubilization activity such as Pantoea ananatis, Rahnella aquatilis, and Enterobacter sp. which were able to solubilize, respectively, 172, 263, and $254 \mu \mathrm{g} \mathrm{ml}^{-1}$ of $\mathrm{Ca}_{3}\left(\mathrm{PO}_{4}\right)_{2}$ after 5 days of growth at $28{ }^{\circ} \mathrm{C}$ and $\mathrm{pH}$ 7.5. Potassium solubilization activity of Pantoea agglomerans, Rahnella aquatilis, and Pseudomonas orientalis were reported equal to 35,76 , and $56 \mu \mathrm{g} \mathrm{ml} l^{-1}$, respectively, of $\mathrm{K}$ in Aleksandrov liquid medium after 21 days of incubation [11]. The $\mathrm{Zn}$ solubilization by Rhizobium sp. and Agrobacterium tumefaciens in tris-mineral medium reached the highest value at $\mathrm{pH} 9$ equal to 72 and $51 \mathrm{mg}^{-1}$, respectively [13].

Since the knowledge of the native beneficial bacterial population, the irrelative abundance in the soil, identification, characterization, and optimization of their growth conditions are important for understanding the performance and diversity of indigenous bacteria in the soil of specific crops, this research aimed to (i) isolate and identify bacterial isolates with biological nitrogen-fixing capability and phosphate, potassium, and zinc solubilization activities from durum wheat field; (ii) develop accurate mathematical models to determine the effect of temperature, $\mathrm{NaCl}$ concentration, and $\mathrm{pH}$ on the growth and activity of selected isolates; (iii) evaluate, by metagenomic approaches, if tillage/notillage management affects the presence of these potentially beneficial bacteria.

\section{Materials and Methods}

\section{Sample Collection}

The sampling was conducted in a Mediterranean soil ecosystem at Lavello (Southern Italy, Basilicata region, located at $41^{\circ} 03^{\prime} \mathrm{N}, 15^{\circ} 42^{\prime} \mathrm{E}$, altitude of $180 \mathrm{~m}$ above the average of sea level, with an average of $570 \mathrm{~mm}$ and $14.5{ }^{\circ} \mathrm{C}$ of long-term annual rainfall and temperature, respectively). Since soil tillage managements have complex effects on soil physical, chemical, and biological properties which could subsequently affect PGPB activity in soil [14], the potentially beneficial bacterial isolation was performed in a field under two different tillage practices including 10 years of conventional tillage (CT) and no-tillage (NT) practices. Both plots have been cultivated for 10 years with a biennial rotation of durum wheat and legumes including broad bean (Vicia faba L.), green pea (Pisum sativum L.), and chickpea (Cicer arietinum L.). In both plots, straw and root residues of durum wheat and legumes have been left on the fields. Three composite soil samples from each plot were collected after harvesting of the durum wheat in 2018. A minimum of five sub-samples were taken randomly by hand auger and combined into one composite sample. Fine fraction passing a $2 \mathrm{~mm}$ sieve was collected and transported refrigerated at $4{ }^{\circ} \mathrm{C}$.

\section{Isolation of Bacterial Strains}

$5 \mathrm{~g}$ of each sample was weighed and then homogenized in a $45 \mathrm{ml}$ sterile Ringer solution and $5 \mathrm{ml}$ pyrophosphate. Microbial communities were desorbed from soil by sonication. Serial dilution $\left(10^{-2}\right.$ to $\left.10^{-6}\right)$ of samples prepared and then poured on Nutrient Agar (NA) plates supplemented with $1 \%(\mathrm{w} / \mathrm{v})$ cycloheximide; the plates were incubated at $30{ }^{\circ} \mathrm{C}$ for $48 \mathrm{~h}$ [15]. The streaking technique was used on NA plates to get single colonies for further investigation.

\section{Isolation of Nitrogen-Fixing Bacteria}

Nitrogen fixation capability of isolates was measured in $\mathrm{N}$-free medium [15] containing $5 \mathrm{~g}$ malic acid, $0.5 \mathrm{~g}$ $\mathrm{KH}_{2} \mathrm{PO}_{4}, 0.2 \mathrm{~g} \mathrm{MgSO}_{4} \cdot 7 \mathrm{H}_{2} \mathrm{O}, 0.1 \mathrm{~g} \mathrm{NaCl}, 4.5 \mathrm{~g} \mathrm{KOH}$, $1.4 \%$ agar, $0.02 \mathrm{~g} \mathrm{CaCl}_{2}, 2 \mathrm{ml}$ micronutrient solution $\left(1^{-1}\right.$; $0.04 \mathrm{~g} \mathrm{CuSO}_{4} \cdot 5 \mathrm{H}_{2} \mathrm{O}, 1.2 \mathrm{~g} \mathrm{ZnSO}_{4} \cdot 7 \mathrm{H}_{2} \mathrm{O}, 1.4 \mathrm{~g} \mathrm{H}_{3} \mathrm{BO}_{3}, 1 \mathrm{~g}$ $\left.\mathrm{Na}_{2} \mathrm{MoO}_{4} \cdot 2 \mathrm{H}_{2} \mathrm{O}, 1.175 \mathrm{~g} \mathrm{MnSO}_{4} \cdot \mathrm{H}_{2} \mathrm{O}\right), 2 \mathrm{ml}$ bromothymol blue $\left(0.5 \%\right.$ sol $\left.0.2 \mathrm{~mol} \mathrm{l}^{-1} \mathrm{KOH}\right), 1 \mathrm{ml} \mathrm{Fe-EDTA} \mathrm{(1.64 \% ),}$ $4 \mathrm{ml}$ vitamins solution $\left(100 \mathrm{ml}^{-1} ; 10 \mathrm{mg}\right.$ biotin, $20 \mathrm{mg}$ piridixol- $\mathrm{HCl}$ ) in $1000 \mathrm{ml}$ deionized water, and $\mathrm{pH}$ was adjusted to 7.0. A loop full of bacterial overnight growth in Nutrient Broth (NB) was spread on solid N-free medium plates. The experiments were made in triplicate, and a blue halo zone after 7 days of incubation at $30^{\circ} \mathrm{C}$ was considered as qualitative evidence of $\mathrm{N}_{2}$ gas fixation.

\section{Selection of Effective Phosphate, Potassium and Zinc-Solubilizing Strains}

Phosphate-solubilizing abilities of all isolated colonies were measured on Pikovskaya agar (PVK) medium [16] containing $10 \mathrm{~g}$ glucose, $5 \mathrm{~g} \mathrm{Ca}_{3}\left(\mathrm{PO}_{4}\right)_{2}, 0.5 \mathrm{~g}\left(\mathrm{NH}_{4}\right)_{2} \mathrm{SO}_{4}, 0.2 \mathrm{~g}$ $\mathrm{NaCl}, 0.1 \mathrm{~g} \mathrm{MgSO}_{4}-7 \mathrm{H}_{2} \mathrm{O}, 0.2 \mathrm{~g} \mathrm{KCl}, 0.5 \mathrm{~g}$ yeast extract, 
$0.0003 \mathrm{~g} \mathrm{MnSO}_{4} \_\mathrm{H}_{2} \mathrm{O}, 0.0003 \mathrm{~g} \mathrm{FeSO}_{4} \_7 \mathrm{H}_{2} \mathrm{O}, 10 \mathrm{~g}$ agar (1000 $\mathrm{ml}$ deionized water), and $\mathrm{pH}$ 7.0.

Potassium-solubilizing ability was also determined on modified Aleksandrov agar medium containing $3.5 \mathrm{~g}$ Glucose, $0.5 \mathrm{~g} \mathrm{MgSO}_{4} \cdot 7 \mathrm{H}_{2} \mathrm{O}, 0.1 \mathrm{~g} \mathrm{CaCO}_{3}, 0.0005 \mathrm{~g} \mathrm{FeCl}_{3}$, $2.0 \mathrm{~g} \mathrm{Ca}_{3} \mathrm{PO}_{4}, 1.0 \mathrm{~g}$ insoluble mica powder as potassium source, and $15.0 \mathrm{~g}$ agar $(1000 \mathrm{ml}$ deionized water and $\mathrm{pH}$ was adjusted 7.0) [17].

Tris-mineral agar medium was used to evaluate zincsolubilizing ability containing $10.0 \mathrm{~g}$ D-glucose, $1.0 \mathrm{~g}$ $\left(\mathrm{NH}_{4}\right)_{2} \mathrm{SO}_{4}, 0.2 \mathrm{~g} \mathrm{KCl}, 0.1 \mathrm{~g} \mathrm{~K}_{2} \mathrm{HPO}_{4}, 0.2 \mathrm{~g} \mathrm{MgSO}_{4}, 1.244 \mathrm{~g}$ zinc oxide $(0.1 \% \mathrm{Zn}$ concentration) in $1000 \mathrm{ml}$ deionized water at $\mathrm{pH} 7.0$ [18].

$\mathrm{P}, \mathrm{K}$, and $\mathrm{Zn}$ solubilization and $\mathrm{N}$ fixation efficiency calculated (Eq. 1) by incubating the isolates on agarized PVK, Aleksandrov, Tris-mineral, and $\mathrm{N}$-free mediums at $29{ }^{\circ} \mathrm{C}$ for 7 days [19].

$\mathrm{NE}=\left(\frac{\mathrm{HZ}}{C}\right) \times 100$,

where NE is the nutrient solubilization or fixation efficiency, $\mathrm{HZ}$ the diameter of the solubilization halo zone, and $C$ is the diameter of the colony.

\section{Quantitative Estimation of $\mathrm{P}, \mathrm{K}$, and Zn Solubilization and N Fixation}

Based on the results of the plate assay, four isolates which showed the best solubilization of phosphate, potassium, and zinc, as well as fixation of nitrogen gas, were subjected to quantify the amount of $\mathrm{P}, \mathrm{K}, \mathrm{Zn}$, and $\mathrm{N}$ in the liquid medium. Accordingly, inoculated and non-inoculated (control) liquid mediums were incubated at $29{ }^{\circ} \mathrm{C}$ in a shaker at $200 \mathrm{rpm}$ for 14 days. Total-reflection X-ray fluorescence spectrometry (TXRF) technique was used to analyses solubilized P, K, and $\mathrm{Zn}$ in the supernatant of the bacterial cultures, as fully described by Yaghoubi et al. [13], using an S2Picofox TXRF Spectrometer (Bruker Nano GmbH, Berlin, Germany). Also, the total $\mathrm{N}$ of liquid samples was determined by the Kjeldahl (Model UDK 149 Automatic Kjeldahl Distillation Unit, VELP Scientifica, Italy) method.

\section{Effect of pH on Solubilizing Ability of PGPB Isolates}

The PVK, Aleksandrov, and Tris-mineral mediums were used to estimate the effect of five $\mathrm{pH}$ values $(6,7,8,9$, and 10 ) on $\mathrm{P}-, \mathrm{K}-$, and $\mathrm{Zn}$-solubilizing ability of selected isolates, respectively, as previously described.

\section{Indole Acetic Acid (IAA) Production}

In vitro production of IAA for each isolate was determined colorimetrically following the method of Gordon and Weber
[20]. The bacteria were grown in NB media supplemented with L-tryptophan $\left(1 \mathrm{mg} \mathrm{ml}^{-1}\right)$ at $30^{\circ} \mathrm{C}$ for $72 \mathrm{~h}$, and then the supernatants were collected by centrifugation at $5500 \mathrm{rpm}$ for $15 \mathrm{~min}$. One $\mathrm{ml}$ of the culture filtrate was allowed to react with $4 \mathrm{ml}$ of Salkowsky reagent $\left(1 \mathrm{ml} 0.5 \mathrm{M} \mathrm{FeCl}_{3} ; 30 \mathrm{ml}\right.$ $\mathrm{H}_{2} \mathrm{SO}_{4} 98 \% ; 50 \mathrm{ml}$ distilled water) at room temperature in the dark for $20 \mathrm{~min}$. The optical density (OD) of solution was read at $535 \mathrm{~nm}$ in a spectrophotometer (Model Ultrospec 4000, Pharmacia Biotech Inc. USA), and the amount of IAA produced was calculated by comparing with the standard curve prepared with pure IAA.

\section{Bacterial DNA Extraction and 16S rRNA Gene Sequencing}

Genomic DNA of isolates was extracted using the DNeasy Blood \& Tissue Kit (Qiagen, Hilden, Germany), and the 16S rRNA gene PCR amplification was performed by the universal primers $357 \mathrm{~F}$ and $1401 \mathrm{R}$, corresponding to the position 341-357 and 1385-1401, respectively, of the 16S rRNA gene sequence of Escherichia coli [21]. All PCR amplifications were carried out in $25 \mu \mathrm{l}$ reactions containing $100 \mathrm{ng}$ of total DNA, $10 \mathrm{mM}$ of each 2'-deoxynucleoside 5 '-triphosfate (dNTP), $3 \mathrm{U}$ of Taq DNA polymerase (EuroTaq; EuroClone), and $2.5 \mathrm{mM} \mathrm{MgCl}_{2}$ using a MyCycler ${ }^{\mathrm{TM}}$ thermal cycler (Bio-Rad Laboratories Inc.). The 1060 bp amplicons were purified using the Wizard ${ }^{\circledR}$ SV Gel and PCR Clean-Up System kit (Promega, USA) and sequenced from both ends by Eurofins Genomics (Milan, Italy). The 16S rRNA sequences were aligned using the BLASTn tool against the NCBI database (www.ncbi.nlm.nih.gov) to identify the bacterial strains.

\section{Soil DNA Extraction and Bacterial Community Analyses}

DNA was extracted from soils using the FastDNA® SPIN Kit for Soil (MP Biomedicals, Solon, CA, USA). Aliquots of the extracted DNA were sent to the IGA Technology Service in Udine (Italy) for metagenomic analyses; the sequencing was performed through the MiSeq Illumina system platform. QIIME software (version 1.9.1) was used to perform bacterial community analysis as fully described by Kuczynski et al. [22]. Amplification of the variable V3 and V4 regions of the 16S rRNA gene was performed in two steps, including a PCR amplification using locus-specific primers and the flow-cell binding sequence (Nextera XT Index Kit, FC-1311001/FC-131-1002). Aligned sequences were clustered into operational taxonomic units (OTUs) with a $97 \%$ similarity cut-off after removing the singletons or non-bacterial OTUs. Bacterial $\alpha$-diversity measures (Good's coverage estimator, Chao1 index, Shannon index, and Simpson index) were computed based on 10,000 reads per samples. A cut-off of 
$50 \%$ of the target sequencing coverage was considered for rarefaction curves endpoints and normalization of counts. A minimum confidence threshold of $50 \%$ was also applied to assign the bacterial taxonomy using the Ribosomal Database Project (RDP) Naïve Bayesian classifier.

\section{Modeling Salt Stress Tolerance of the Selected Bacteria}

Different $\mathrm{NaCl}$ concentrations including 0.5 (control treatment), $1,1.5,2$, and $3 \%(\mathrm{w} / \mathrm{v}$ ) were used to estimate the bacterial growth under salt stress $(\mathrm{NaCl})$ in Nutrient Broth $(\mathrm{NB})$ medium. The bacterial growth was evaluated by measuring the turbidity at $600 \mathrm{nmin} 0,5,9,15,20,24,29,33$, and $48 \mathrm{~h}$ of incubation at $29^{\circ} \mathrm{C}$. A logistic equation (Eq. 2) was used to predict the influence of $\mathrm{NaCl}$ concentration on isolates growth. Equation (3) is used to estimate the rate of absorbance increase over time (absorbance per hour) at different $\mathrm{NaCl}$ concentrations of NB medium [13, 23].

$\mathrm{Ab}=\frac{\mathrm{Ab}_{\max }}{1+x / x 50^{s}}$,

where $\mathrm{Ab}$ is absorbance at concentration $x, \mathrm{Ab}_{\max }$ is maximum absorbance, $x_{50}$ is concentration of $\mathrm{NaCl}$ required for $50 \%$ inhibition of the maximum absorbance, and $s$ is slope of the curve in $x_{50}$.

$W=\frac{W_{\max }}{1+\mathrm{e}^{-k\left(t-t_{m}\right)}}$,

where, $w$ is the absorbance value at time $t, k$ is a constant that determines the curvature of the growth pattern, and $t_{m}$ is the inflection point when the absorbance rate reaches the peak. The absorbance value at $t_{\mathrm{m}}$ is half of its maximum value $\left(w_{\max }\right)$.

\section{Modeling the Effect of Temperature on Solubilizing Ability of Selected Bacteria}

Four constant temperatures $\left(4{ }^{\circ} \mathrm{C}, 18{ }^{\circ} \mathrm{C}, 30^{\circ} \mathrm{C}\right.$, and $\left.40{ }^{\circ} \mathrm{C}\right)$ were subjected to propose mathematical models for prediction of the beneficial bacterial growth in NB medium during $34 \mathrm{~h}$ of incubation. The turbidity of the culture was estimated at $600 \mathrm{~nm}$. Equation (3) is used to quantify the response of potentially beneficial bacterial isolates to temperatures [6]. A modified beta model (Eq. 4) was used to predict the rate of absorbance increase over time (absorbance per hour) at different temperature levels of incubation [24]:

$$
\begin{array}{ll}
f(T)=\left(\frac{T_{\mathrm{c}}-T}{T_{\mathrm{c}}-T_{\mathrm{o}}}\right)\left(\frac{T-T_{\mathrm{b}}}{T_{\mathrm{o}}-T_{\mathrm{b}}}\right)^{\left(\frac{T_{\mathrm{o}}-T_{\mathrm{b}}}{T_{\mathrm{c}}-T_{\mathrm{b}}}\right)} & \text { if } T>T_{\mathrm{b}} \text { and } T<T_{\mathrm{c}} \\
f(T)=1 & \text { if } T=T_{\mathrm{o}} \\
f(T)=0 & \text { if } T \leq T_{\mathrm{b}} \text { or } T \leq T_{\mathrm{c}}
\end{array},
$$

where $T$ is the temperature, $T_{\mathrm{b}}$ the base temperature, $T_{\mathrm{o}}$ the optimum temperature, and $T_{\mathrm{c}}$ the ceiling temperature. The parameters were estimated by the least-squares method using the non-linear regression procedure and repeated optimization method.

\section{Data Analysis}

Differences among treatment mean (the least significant difference (LSD) test) was calculated using the SPSS software (ver. 16.0 for windows) at a significance level of 0.05 . Modeling analyses along with the determination of standard deviation, coefficient of variation, the coefficient of determination, and root-mean-square error as well as the drawing the regression graphs were performed using SigmaPlot software (ver. 14).

\section{Results}

\section{Isolation of $\mathrm{P}, \mathrm{K}$, and $\mathrm{Zn}$ Solubilizing and $\mathrm{N}_{\mathbf{2}}$ Fixing Bacteria}

All bacterial isolates were screened after 3 and 7 days of incubation to determine their $\mathrm{P}, \mathrm{K}$, and $\mathrm{Zn}$ solubilization and $\mathrm{N}$ fixation efficiency on the isolation plates. Accordingly, 17, 14 , and 4 isolates were able to produce a clear zone around their colonies on the Pikovskaya, Aleksandrov, and Trismineral medium, respectively (Table 1 ). In detail, $18.6 \%$, $15.4 \%$, and $4.4 \%$ of isolates were able to solubilize $\mathrm{P}, \mathrm{K}$, and $\mathrm{Zn}$ from insoluble compounds in solid mediums. There was not any blue zone around isolates colonies on solid $\mathrm{N}$-free medium after 3 days of incubation, but the appearance of blue zone was considered as a qualitative evidence of $\mathrm{N}_{2}$ fixation for four isolates after 7 days of incubation (Table 1).

The results of further examination of the potentially beneficial bacterial solubilization and fixation activity in the corresponding liquid medium, after 14 days of inoculation, are presented in Figs. 1, 2, and Table 2. In this regard, the amounts of $\mathrm{P}$ release from insoluble phosphate compound by the four best phosphate-solubilizing bacteria (PSB) ranged from 11.1 to $115.5 \mathrm{mg} \mathrm{l}^{-1}$. Isolate NT28 had significantly higher P-solubilization ability as compared to other isolates (NT9, NT10, and NT6) (Fig. 1a).

The amount of $\mathrm{K}$ released by potassium-solubilizing bacteria (KSB) ranged from 32.2 (isolate NT15) to 35.6 (isolate CT21) $\mathrm{mg} \mathrm{l}^{-1}$, which were not significantly different from each other (Fig. 1d). The maximum solubilization occurred when the KSB activities significantly decreased the $\mathrm{pH}$ of the medium during the incubation (Fig. 1e). Four NFB isolates showed biological $\mathrm{N}_{2}$ fixation activity in liquid $\mathrm{N}$-free medium in a range of $\mathrm{NH}_{4}-\mathrm{N}$ from 19.9 to $25.2 \mu \mathrm{g} \mathrm{ml}^{-1}$. The highest $\mathrm{N}_{2}$ fixation ability was belonged 
Table $1 \mathrm{P}, \mathrm{K}$, and $\mathrm{Zn}$ solubilization and $\mathrm{N}$ fixation efficiency after 3 and 7 days of incubation

\begin{tabular}{|c|c|c|c|c|c|}
\hline \multirow[t]{2}{*}{ Isolates } & \multicolumn{2}{|l|}{$\mathrm{PE}(\%) \pm \mathrm{SD}$} & \multirow[t]{2}{*}{ Isolates } & \multicolumn{2}{|l|}{$\mathrm{KE}(\%) \pm \mathrm{SD}$} \\
\hline & 3 days & 7 days & & 3 days & 7 days \\
\hline NT9 & $196 \pm 7$ & $200 \pm 10$ & NT6 & $191 \pm 7$ & $192 \pm 6$ \\
\hline NT10 & $162 \pm 4$ & $186 \pm 11$ & CT21 & $175 \pm 9$ & $192 \pm 18$ \\
\hline NT6 & $172 \pm 10$ & $183 \pm 6$ & NT15 & $155 \pm 22$ & $188 \pm 21$ \\
\hline NT28 & $165 \pm 8$ & $181 \pm 8$ & NT28 & $136 \pm 12$ & $185 \pm 11$ \\
\hline CT63 & $160 \pm 3$ & $174 \pm 9$ & CT45 & $142 \pm 7$ & $181 \pm 12$ \\
\hline СТ30 & $141 \pm 8$ & $172 \pm 15$ & CT64 & $175 \pm 1$ & $178 \pm 19$ \\
\hline СТ34 & $142 \pm 15$ & $166 \pm 7$ & CT16 & $146 \pm 14$ & $173 \pm 6$ \\
\hline CT35 & $150 \pm 10$ & $164 \pm 5$ & CT67 & $159 \pm 3$ & $171 \pm 7$ \\
\hline CT32 & $161 \pm 2$ & $161 \pm 5$ & CT44 & $144 \pm 6$ & $166 \pm 17$ \\
\hline CT15 & $147 \pm 6$ & $160 \pm 18$ & NT1 & $166 \pm 8$ & $165 \pm 5$ \\
\hline CT59 & $135 \pm 4$ & $150 \pm 6$ & CT9 & $147 \pm 14$ & $158 \pm 4$ \\
\hline NT1 & $136 \pm 5$ & $142 \pm 8$ & NT10 & $155 \pm 9$ & $155 \pm 1$ \\
\hline CT5 & $134 \pm 2$ & $136 \pm 7$ & СТ34 & $152 \pm 3$ & $154 \pm 3$ \\
\hline NT5 & - & $134 \pm 4$ & NT9 & $152 \pm 8$ & $143 \pm 4$ \\
\hline CT13 & $123 \pm 6$ & $131 \pm 7$ & & & \\
\hline NT29 & - & $121 \pm 2$ & & & \\
\hline NT20 & - & $118 \pm 6$ & & & \\
\hline Isolates & $\mathrm{ZnE}(\%) \pm \mathrm{SD}$ & & Isolates & $\mathrm{NE}(\%) \pm \mathrm{SD}$ & \\
\hline NT6 & $233 \pm 12$ & $250 \pm 23$ & NT3 & - & $136 \pm 5$ \\
\hline NT1 & $214 \pm 16$ & $229 \pm 21$ & NT2 & - & $123 \pm 3$ \\
\hline NT10 & $212 \pm 12$ & $224 \pm 18$ & NT31 & - & $117 \pm 1$ \\
\hline СТ34 & $205 \pm 14$ & $213 \pm 13$ & CT43 & - & $115 \pm 1$ \\
\hline
\end{tabular}

SD: standard deviation; PE, KE, and ZnE: P, K, and Zn solubilization efficiency, respectively; NE: nitrogen fixation efficiency, NT: no tillage, CT: conventional tillage

to NT3 isolate which was significantly higher than the other isolates (Fig. 2).

The results showed that the $\mathrm{Zn}$-solubilizing bacteria (ZSB) activities were affected by the $\mathrm{pH}_{\mathrm{m}}$ of the Tris-mineral medium. All four ZSB isolates did not have solubilization activity at $\mathrm{pH} 6$ and 7, while $\mathrm{Zn}$ solubilization was observed in the range of $\mathrm{pH} 8-10$ (Table 2), although these isolates were able to produce a clear zone around their colonies on Tris-mineral agar medium at $\mathrm{pH} 7$ (data not shown). The highest $\mathrm{Zn}$ solubilization $\left(389.9 \mathrm{mg} \mathrm{l}^{-1}\right)$ was observed at $\mathrm{pH}$ 9 for isolate NT10, which was significantly higher than other isolates. A decrease in the $\mathrm{pH}$ of the Tris-mineral medium after 14 days of incubation was observed at starting $\mathrm{pH}$ values from 7 to 10 , and the final $\mathrm{pH}$ of the medium increased to 6.5-6.8 when the incubation $\mathrm{pH}$ was 6.0 (Table 2).

There were also significant differences among the capacity of these isolates to produce IAA in the presence of L-tryptophan. Almost all strains produced amounts of IAA from 3 to $8 \mu \mathrm{g} \mathrm{ml}^{-1}$, while only one isolate (NT28) showed a very high capacity to $21 \mu \mathrm{g} \mathrm{ml}^{-1}$ (Fig. 3).

One of the strains for each experiment with the highest solubilization and fixation efficiency (NT28, CT21, NT10, and NT3, as PSB, KSB, ZSB, and NFB, respectively) was used for further analysis such as regression analysis and mathematical models. According to the results, cubic and quadratic regressions significantly fitted the relationship between the $\mathrm{pH}$ of PVK medium before the incubation $\left(\mathrm{pH}_{\mathrm{m}}\right)$ and two other parameters that are the $\mathrm{pH}$ of medium after incubation period $\left(\mathrm{pH}_{\mathrm{f}}\right)$ and solubilized $\mathrm{P}$ by NT28 isolate activity, respectively (Fig. 1c). As the $\mathrm{pH}_{\mathrm{f}}$ decreased by NT28 activity, the P solubilizing increased significantly. The maximum P solubilization of NT28 was obtained at $\mathrm{pH}_{\mathrm{m}} 8\left(136.6 \mathrm{mg} \mathrm{l}^{-1}\right)$, which was $18 \%$ and $23 \%$ more than that at $\mathrm{pH}_{\mathrm{m}} 7$ and 9 , respectively. Conversely, its $\mathrm{pH}_{\mathrm{f}}$ value was $2.1 \%$ and $19.6 \%$ lower than that in $\mathrm{pH}_{\mathrm{m}}$ 7 and 9 , respectively. In fact, the more the decreasing of $\mathrm{pH}_{\mathrm{f}}$ in the medium by bacterial activities, the more the solubilizing activity.

Regression of cubic equation models significantly $(P<0.01)$ fit correlations between $\mathrm{pH}_{\mathrm{m}}$ and $\mathrm{pH}_{\mathrm{f}}$, as well as $\mathrm{pH}_{\mathrm{m}}$ and solubilized $\mathrm{K}$; the coefficients of determination $\left(r^{2}\right)$ of the equations were 0.77 and 0.92 , respectively. The highest amount of solubilization $\mathrm{K}$ belonged to $\mathrm{pH}_{\mathrm{m}} 7$, which was significantly higher than that in other $\mathrm{pH}_{\mathrm{m}}$ (Fig. 1f). 


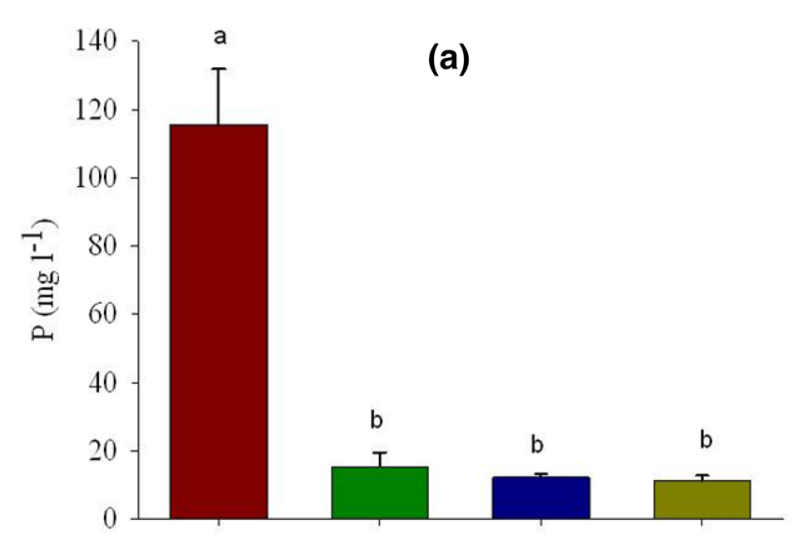

(b)
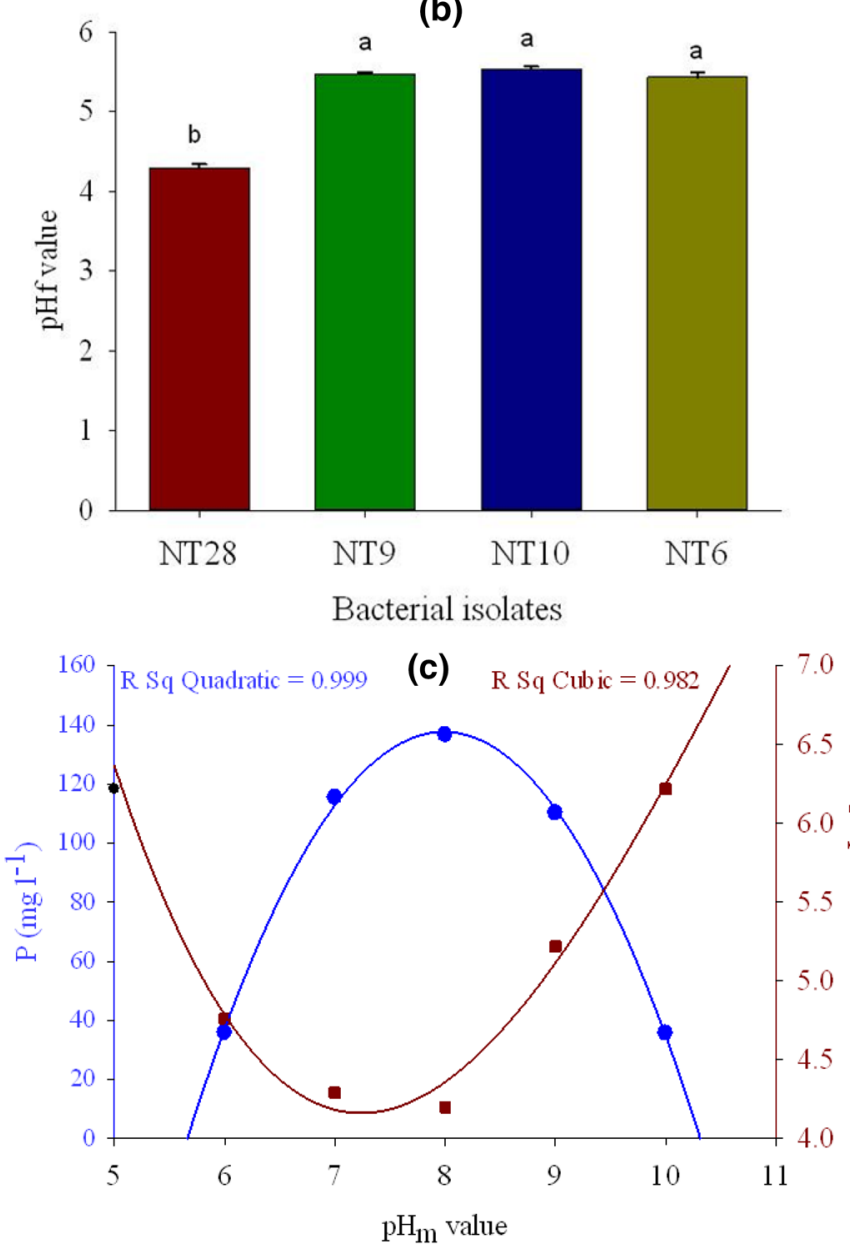

Fig. 1 Quantitative estimation of $\mathrm{P}$ solubilization $\left(\mathrm{mg} \mathrm{l}^{-1}\right)(\mathbf{a}) ; \mathrm{pH}$ of PVK medium after the 14 days of incubation $\left(\mathrm{pH}_{\mathrm{f}}\right)$ at starting $\mathrm{pH}$ of $7\left(\mathrm{pH}_{\mathrm{m}}\right)(\mathbf{b})$; relationship between the $\mathrm{pH}_{\mathrm{m}}$ and $\mathrm{pH}_{\mathrm{f}}$ and solubilized $\mathrm{P}$ $\left(\mathrm{mg} \mathrm{l}^{-1}\right)$ by PSB strain (NT28) (c). Quantitative estimation of K solubilization $\left(\mathrm{mg} \mathrm{l}^{-1}\right)(\mathbf{d}) ; \mathrm{pH}_{\mathrm{f}}$ of Aleksandrov medium at $\mathrm{pH}_{\mathrm{m}}$ of $7(\mathbf{e})$;

\section{Molecular Identification of Potentially Beneficial Bacteria and Their Relative Abundance in the Soil}

The results of 16S rRNA gene sequencing were compared
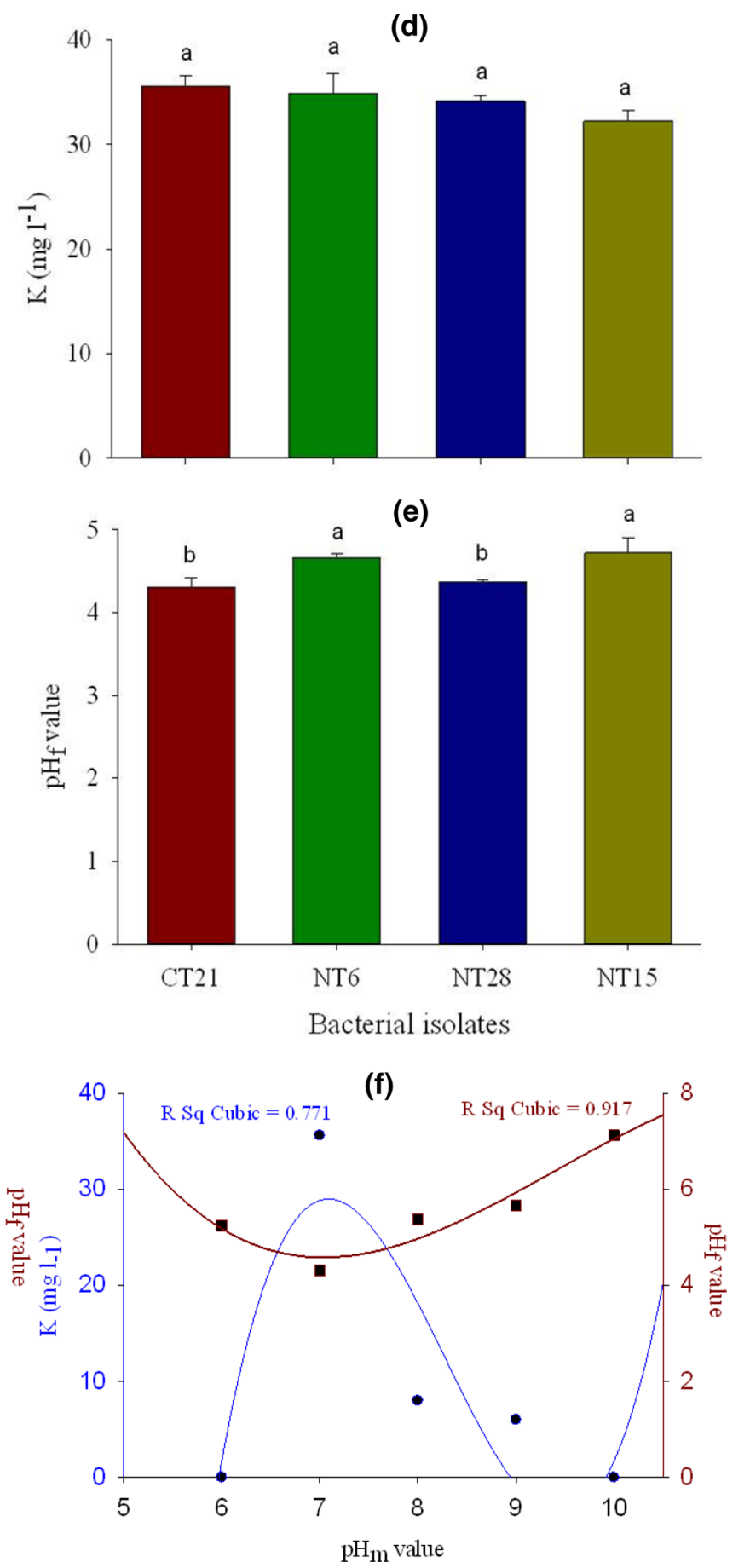

relationship between the $\mathrm{pH}_{\mathrm{m}}$ and $\mathrm{pH}_{\mathrm{f}}$ and solubilized $\mathrm{K}\left(\mathrm{mg} \mathrm{l}^{-1}\right)$ by KSB strain (CT21) (f). Means followed by the same letter(s) are not significantly different based on the least significant difference (LSD) test at 0.05 probability level

to those of known 16S rRNA sequences using BLAST and the GenBank database (Table 3). Accordingly, 12 strains belonged to 3 different genera (sequence identity $>98 \%$ ) including Pseudomonas, Acinetobacter, and Comamonas. 


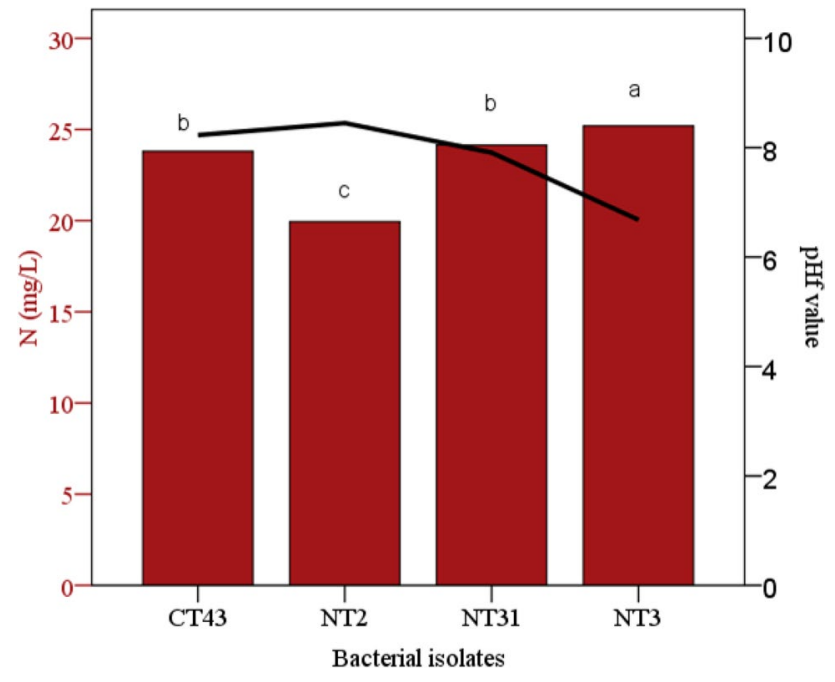

Fig. 2 Quantitative estimation of $\mathrm{N}_{2}$ fixation $\left(\mathrm{mg}^{-1}\right)$ by NFB strain (NT3) activity and final $\mathrm{pH}$ of $\mathrm{N}$-free semi-solid medium after the 14 days of incubation $\left(\mathrm{pH}_{\mathrm{f}}\right)$. Means followed by the same letter are not significantly different based on the least significant difference (LSD) test at 0.05 probability level

the best PSB, KSB, ZSB, and NFB strains were Acinetobacter pittii, Acinetobacter oleivorans, Acinetobacter calcoaceticus, and Comamonas testosteroni, respectively (Table 3). Relative abundances (\%) of bacterial Phyla ( $>1 \%$ ) are given in Fig. 4a. The most abundant phylum in the CT and NT soil samples was Proteobacteria, equal to 27.5 and $27.8 \%$ of the total sequences, followed by Actinobacteria ( 24.5 and $23.7 \%$ ), respectively. Among the less represented phyla, Firmicutes and Verrucomicrobia were more abundant in CT plots as compared to the NT soils, while Bacteroidetes and Planctomycetes were significantly more present in the NT soil samples (Fig. 4a). Nine abundant families with a relative abundance $>2 \%$ were detected in soil samples (Fig. 4b). Accordingly, Bacillaceae and Chthoniobacteraceae were significantly more abundant in the CT soils as compared to the NT soils. Conversely, the significantly greater relative abundance of Bradyrhizobiaceae, Chitinophagaceae, and Nocardioidaceae detected in the NT samples (Fig. 4b).

The comparison of the presence of phylum, families, and genera where our potentially beneficial bacteria belong to, in NT and CT soil samples, are presented in Table 4. All 12 bacterial strains belonged to the Proteobacteria phylum and three families (Moraxellaceae, Pseudomonadaceae, and Comamonadaceae), which were more present in the NT samples as compared to the $\mathrm{CT}$, although only significantly for Pseudomonadaceae $(P<0.01)$. Similarly, at the genera level, the presence of Pseudomonas and Comamonas genera in NT was significantly higher when compared to the CT (Table 4).

The number of 410,128 high-quality sequences was detected with a 300-bp read length. Good's coverage rate (0.86) showed that the number of sequencing reads was sufficient to estimate bacterial diversity (Table 5). There was no significant difference between $\mathrm{CT}$ and NT samples in terms of the Simpson index, while the rate of Chaol estimator and Shannon index in the NT was significantly higher than those in the CT samples (Table 5).

\section{Bacterial Growth Under Different $\mathrm{NaCl}$ Concentrations}

The growth of the bacterial strains was influenced by different salinity levels under in vitro conditions. The $\mathrm{NaCl}$ concentration required for 50\% inhibition of absorbance $\left(X_{50}\right)$ was about $2.6-3.7 \%$. The maximum bacterial growth $\left(A b_{\max }\right)$ was observed in a range of $0.6 \%$ (KSB strain) $-0.92 \%$ (NFB strain) $\mathrm{NaCl}$ concentration, which was more than that in control $(0.5 \% \mathrm{NaCl})$. According to the modeling analyses, a complete inhibition was estimated at $9.3 \% \mathrm{NaCl}$ for Comamonas testosteroni (NT3, NFB strain), which was

Table 2 Values of $\mathrm{Zn}$ solubilization $\left(\mathrm{mg} \mathrm{l}^{-1}\right)$ determined at different $\mathrm{pH}$ levels of liquid Tris-mineral medium

\begin{tabular}{|c|c|c|c|c|c|c|c|c|c|c|}
\hline \multirow[t]{2}{*}{ Isolates } & \multicolumn{2}{|l|}{$\mathrm{pH}_{\mathrm{m}}=6$} & \multicolumn{2}{|l|}{$\mathrm{pH}_{\mathrm{m}}=7$} & \multicolumn{2}{|l|}{$\mathrm{pH}_{\mathrm{m}}=8$} & \multicolumn{2}{|l|}{$\mathrm{pH}_{\mathrm{m}}=9$} & \multicolumn{2}{|l|}{$\mathrm{pH}_{\mathrm{m}}=10$} \\
\hline & $\mathrm{Zn}(\mathrm{SD})$ & $\mathrm{pH}_{\mathrm{f}}(\mathrm{SD})$ & $\mathrm{Zn}(\mathrm{SD})$ & $\mathrm{pH}_{\mathrm{f}}(\mathrm{SD})$ & $\mathrm{Zn}(\mathrm{SD})$ & $\mathrm{pH}_{\mathrm{f}}(\mathrm{SD})$ & $\mathrm{Zn}(\mathrm{SD})$ & $\mathrm{pH}_{\mathrm{f}}(\mathrm{SD})$ & $\mathrm{Zn}(\mathrm{SD})$ & $\mathrm{pH}_{\mathrm{f}}(\mathrm{SD})$ \\
\hline NT6 & 0 & $\begin{array}{l}6.52^{\mathrm{a}} \\
(0.12)\end{array}$ & 0 & $\begin{array}{l}6.78^{\mathrm{a}} \\
(0.07)\end{array}$ & $\begin{array}{l}1.21^{\mathrm{c}} \\
(0.23)\end{array}$ & $\begin{array}{l}7.12^{\mathrm{ab}} \\
(0.11)\end{array}$ & $\begin{array}{l}91.80^{b} \\
(21.73)\end{array}$ & $\begin{array}{l}7.32^{\mathrm{a}} \\
(0.12)\end{array}$ & 0 & $\begin{array}{l}9.12^{\mathrm{ab}} \\
(0.19)\end{array}$ \\
\hline NT1 & 0 & $\begin{array}{l}6.82^{\mathrm{a}} \\
(0.19)\end{array}$ & 0 & $\begin{array}{l}6.76^{\mathrm{a}} \\
(0.08)\end{array}$ & $\begin{array}{l}37.01^{\mathrm{a}} \\
(6.54)\end{array}$ & $\begin{array}{l}6.95^{\mathrm{b}} \\
(0.09)\end{array}$ & $\begin{array}{l}3.20^{\mathrm{c}} \\
(0.54)\end{array}$ & $\begin{array}{l}7.93^{\mathrm{a}} \\
(0.04)\end{array}$ & 0 & $\begin{array}{l}8.86^{\mathrm{b}} \\
(0.24)\end{array}$ \\
\hline NT10 & 0 & $\begin{array}{l}6.62^{\mathrm{a}} \\
(0.12)\end{array}$ & 0 & $\begin{array}{l}6.56^{\mathrm{b}} \\
(0.20)\end{array}$ & $\begin{array}{l}17.09^{b} \\
(4.63)\end{array}$ & $7.15^{\mathrm{ab}}(0.16)$ & $389.90^{\mathrm{a}}(42.43)$ & $\begin{array}{l}6.98^{\mathrm{a}} \\
(0.13)\end{array}$ & $126.82(54.51)$ & $\begin{array}{l}7.38^{\mathrm{c}} \\
(0.17)\end{array}$ \\
\hline СТ34 & 0 & $\begin{array}{l}6.55^{\mathrm{a}} \\
(0.04)\end{array}$ & 0 & $\begin{array}{l}6.69^{\mathrm{ab}} \\
(0.17)\end{array}$ & 0 & $\begin{array}{l}7.33^{\mathrm{a}} \\
(0.07)\end{array}$ & $\begin{array}{l}1.11^{\mathrm{c}} \\
(0.31)\end{array}$ & $\begin{array}{l}7.76^{\mathrm{a}} \\
(0.15)\end{array}$ & 0 & $9.36^{\mathrm{a}}(0.11)$ \\
\hline
\end{tabular}

$\mathrm{pH}_{\mathrm{m}}$ : the $\mathrm{pH}$ of medium culture before the incubation period; $\mathrm{pH}_{\mathrm{f}}$ : the $\mathrm{pH}$ of medium culture after the 14 days of incubation period; $\mathrm{Zn}$ : $\mathrm{zinc}$ solubilization activity $\left(\mathrm{mg} \mathrm{l}^{-1}\right)$; SD: standard deviation

Means in each column followed by the same letter(s) are not significantly different based on the least significant difference (LSD) test at 0.05 probability level 


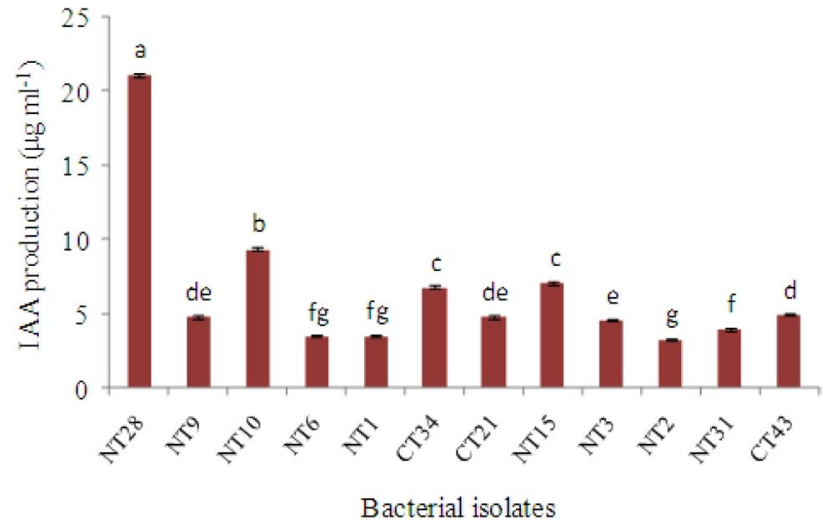

Fig. 3 IAI production with and without L-tryptophan $\left(\mu \mathrm{g} \mathrm{ml}^{-1}\right)$ after $72 \mathrm{~h}$ of incubation. Means followed by the same letter(s) are not significantly different based on the least significant difference (LSD) test at 0.05 probability level

$91 \%, 165 \%$, and $51 \%$ more than Acinetobacter oleivorans (CT21, KSB strain), Acinetobacter pittii (NT28, PSB strain), and Acinetobacter calcoaceticus (NT10, ZSB strain), respectively (Table 6A). The maximum rate of absorbance $\left(W_{\max }\right)$ under different salt concentrations and after $48 \mathrm{~h}$ of incubation is presented in Table 6. Accordingly, the maximum growth belonged to Comamonas testosteroni, NFB strain, in each $\mathrm{NaCl}$ concentration. The time (hours) required to provide the ending of the linear stage is around $24-27 \mathrm{~h}$ for KSB strain, 18-22 h for PSB strain, 21-23 h for ZSB strain, and 20-22 $\mathrm{h}$ for NFB strain, at different $\mathrm{NaCl}$ concentrations, where this inflection point indicated the half of its maximum value $\left(w_{\max }\right)$ (Table $\left.6 \mathrm{~B}\right)$.

\section{Bacterial Growth Under Different Temperatures}

Since all biological processes are affected by temperature, the growth of these bacterial strains was estimated at different temperatures using Eq. 4 and characterized by three cardinal temperatures including base $\left(T_{\mathrm{b}}\right)$, optimum $\left(T_{\mathrm{o}}\right)$, and ceiling $\left(T_{\mathrm{c}}\right)$ temperatures. The minimum $\left(T_{\mathrm{b}}\right)$ and maximum $\left(T_{\mathrm{c}}\right)$ temperatures, estimated by the model, were 2.8 and $45.1^{\circ} \mathrm{C}$ for Acinetobacter oleivorans (KSB strain), 2 and $44.6{ }^{\circ} \mathrm{C}$ for Acinetobacter pittii (PSB strain), 2.3 and $46^{\circ} \mathrm{C}$ for Acinetobacter calcoaceticus (ZSB strain), and 2.1 and $42.18{ }^{\circ} \mathrm{C}$ for Comamonas testosteroni (NFB strain), respectively. Also, the estimated optimal growth temperatures $\left(T_{\mathrm{o}}\right)$ were $24.6,28.2,27.4$, and $23.3{ }^{\circ} \mathrm{C}$, respectively (Table $7 \mathrm{~A}$ ). The maximum absorbance rates $\left(W_{\max }\right)$ after $34 \mathrm{~h}$ of incubation at different temperatures are given in Table 7 . The inflection point of the function, where the function changes concavity, was widely ranged from $17.9 \mathrm{~h}$ to $26.2 \mathrm{~h}$ at $4{ }^{\circ} \mathrm{C}$, $16.8 \mathrm{~h}$ to $19.5 \mathrm{~h}$ at $18^{\circ} \mathrm{C}, 12.1 \mathrm{~h}$ to $16.6 \mathrm{~h}$ at $30^{\circ} \mathrm{C}$, and $17 \mathrm{~h}$ to $23.8 \mathrm{~h}$ at $40^{\circ} \mathrm{C}$, respectively (Table $7 \mathrm{~B}$ ).

Table 3 Identification of selected PGPB isolates based on 16S rRNA gene sequencing, and the genome sequences of the authentic type strains of the corresponding species

\begin{tabular}{|c|c|c|c|c|c|c|}
\hline \multirow[t]{2}{*}{ Bacterial isolates } & \multirow[t]{2}{*}{ Isolation source } & \multirow{2}{*}{$\begin{array}{l}\text { Activity in culture } \\
\text { medium as }\end{array}$} & \multirow[t]{2}{*}{ NCBI accession no. } & \multicolumn{3}{|l|}{ Identified as } \\
\hline & & & & Type strain & $\begin{array}{l}\text { Published species } \\
\text { designation (suggested } \\
\text { designation) }\end{array}$ & Similarity (\%) \\
\hline NT28 & NT soil & PSB and KSB & МT974044 & DSM $21653^{\mathrm{T}}$ & Acinetobacter pittii & 99.7 \\
\hline NT9 & NT soil & PSB & MT974040 & $\mathrm{JCM} 5962^{\mathrm{T}}$ & $\begin{array}{l}\text { Pseudomonas aerugi- } \\
\quad \text { nosa }\end{array}$ & 98.9 \\
\hline NT10 & NT soil & PSB and ZSB & MT974039 & NCCB $22016^{\mathrm{T}}$ & $\begin{array}{l}\text { Acinetobacter calcoace- } \\
\text { ticus }\end{array}$ & 99.1 \\
\hline NT6 & NT soil & $\mathrm{PSB}, \mathrm{KSB}$, and ZSB & MT974053 & ATCC $14235^{\mathrm{T}}$ & $\begin{array}{l}\text { Pseudomonas resino- } \\
\text { vorans }\end{array}$ & 99.1 \\
\hline NT1 & NT soil & $\mathrm{KSB}, \mathrm{ZSB}$ & MT974045 & ATCC $14235^{\mathrm{T}}$ & $\begin{array}{l}\text { Pseudomonas resino- } \\
\text { vorans }\end{array}$ & 99.1 \\
\hline СТ34 & CT soil & ZSB & MT974036 & ATCC $14235^{\mathrm{T}}$ & $\begin{array}{l}\text { Pseudomonas resino- } \\
\text { vorans }\end{array}$ & 99.1 \\
\hline $\mathrm{CT} 21$ & CT soil & KSB & MT974043 & $\mathrm{DR} 1^{\mathrm{T}}$ & Acinetobacter oleivorans & 98.2 \\
\hline NT15 & NT soil & KSB & MT974038 & $\mathrm{DR} 1^{\mathrm{T}}$ & Acinetobacter oleivorans & 99.6 \\
\hline NT3 & NT soil & NFB & MT974042 & $\mathrm{KS} 0043^{\mathrm{T}}$ & Comamonas testosteroni & 99.9 \\
\hline NT2 & NT soil & NFB & MT974041 & ATCC $14235^{\mathrm{T}}$ & $\begin{array}{l}\text { Pseudomonas resino- } \\
\text { vorans }\end{array}$ & 99.0 \\
\hline NT31 & NT soil & NFB & МT974049 & ATCC $14235^{\mathrm{T}}$ & $\begin{array}{l}\text { Pseudomonas resino- } \\
\text { vorans }\end{array}$ & 99.0 \\
\hline CT43 & CT soil & NFB & МT974037 & DSM $50071^{\mathrm{T}}$ & $\begin{array}{l}\text { Pseudomonas aerugi- } \\
\quad \text { nosa }\end{array}$ & 95.6 \\
\hline
\end{tabular}



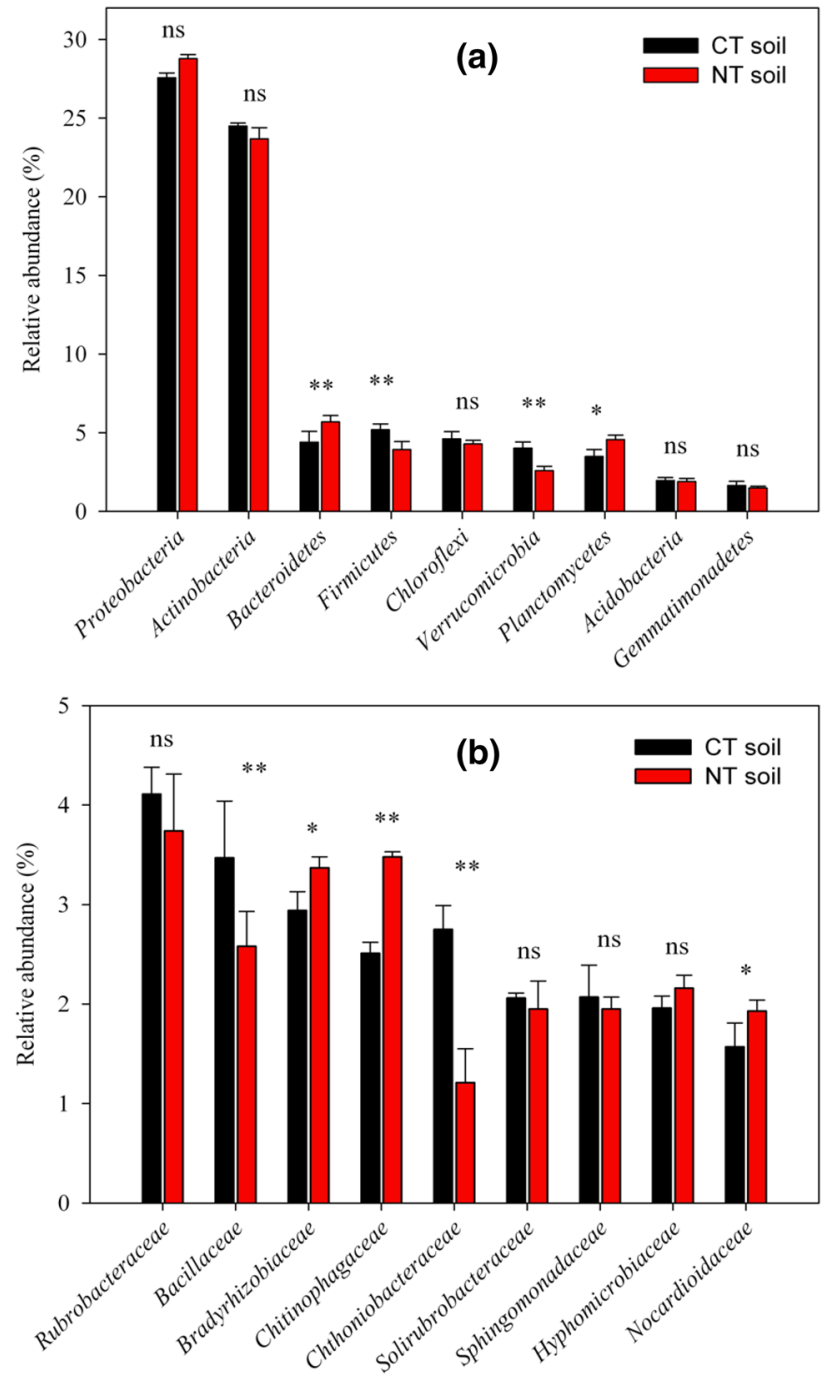

Fig. 4 Relative abundance of a bacterial phyla (relative abundance $>1 \%$ ) and $\mathbf{b}$ families (relative abundance $>2 \%$ ) for bacterial communities under conventional tillage (CT) and no tillage (NT)

\section{Discussion}

Since the composition of potentially beneficial bacterial communities and their colonization capacity in soil are affected by management practices such as tillage [25], the bacterial isolation was performed at a field with two different tillage practices including CT and NT. The present study showed that most of beneficial bacterial isolates $(81 \%$ of the isolates with the best plant growth-promoting traits such as higher solubilization and fixation efficiency) belonged to the no-tillage soil. This finding suggests that the PGPB colonization could be enhanced under NT practice [25] because NT causes slow changes in microbial composition communities [26]. In this regard, Torabian et al. [14] reported that $\mathrm{N}_{2}$ fixation in some crops such as soybean and chickpea were greater under NT than that under CT.

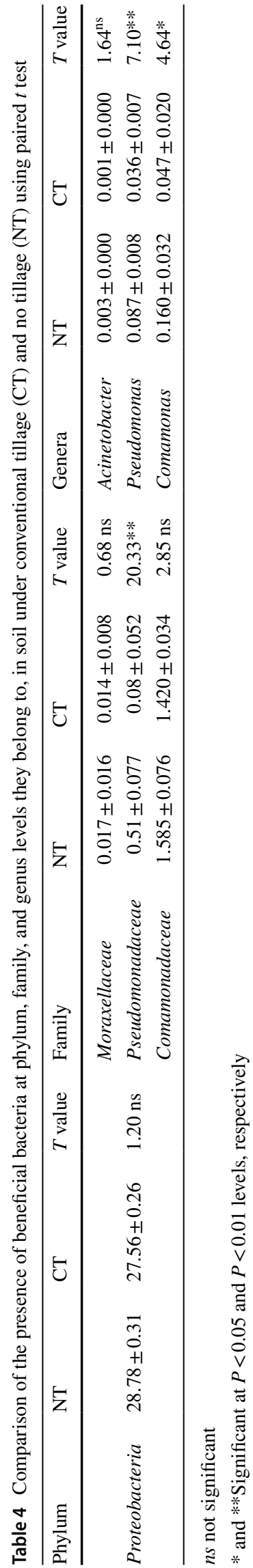


Table 5 Comparison of $\alpha$-diversity indexes (means \pm standard error) of bacterial communities under conventional tillage (CT) and no tillage (NT) using paired $t$ test (sequence count: 10,000)

\begin{tabular}{lllll}
\hline Samples & CHAO1 \pm & Shannon & Simpson & Goods-coverage \\
\hline CT soil & $4544.27 \pm 276.05$ & $9.81 \pm 0.12$ & $0.99 \pm 0.01$ & $0.86 \pm 0.00$ \\
NT soil & $4852.22 \pm 64.94$ & $9.94 \pm 0.04$ & $0.99 \pm 0.00$ & $0.86 \pm 0.00$ \\
T value & $6.69^{*}$ & $6.75^{*}$ & $1.00 \mathrm{~ns}$ & $0.22 \mathrm{~ns}$ \\
\hline
\end{tabular}

$n s$ not significant

*Significant at $P<0.05$ levels

Table 6 Effects of different $\mathrm{NaCl}$ concentrations on the PGPB growth

\begin{tabular}{lllll}
\hline Parameters & KSB isolate (CT21) & PSB isolate (NT28) & ZSB isolate (NT10) & $\begin{array}{l}\text { NFB isolate } \\
(\text { NT3) }\end{array}$ \\
\hline$(\mathrm{A})$ & & & & \\
$\mathrm{Ab}$ & & & & \\
$\max \pm \mathrm{SE}$ & $0.67 \pm 0.03$ & $0.78 \pm 0.06$ & $0.64 \pm 0.94$ & $0.92 \pm 0.01$ \\
$x_{50} \pm \mathrm{SE}$ & $2.58 \pm 0.13$ & $2.65 \pm 0.26$ & $2.77 \pm 0.17$ & $3.68 \pm 0.01$ \\
$S \pm \mathrm{SE}$ & $4.83 \pm 1.11$ & $3.50 \pm 1.36$ & $6.04 \pm 2.39$ & $9.26 \pm 1.75$ \\
$R^{2}$ & 0.98 & 0.94 & 0.95 & 0.99 \\
\hline
\end{tabular}

\begin{tabular}{|c|c|c|c|c|c|}
\hline $\mathrm{NaCl}$ concentrations & Parameters & & & & \\
\hline \multicolumn{6}{|l|}{ (B) } \\
\hline \multirow[t]{4}{*}{$0.5 \%$} & $W_{\max } \pm \mathrm{SE}$ & $0.74 \pm 0.03$ & $0.79 \pm 0.04$ & $0.70 \pm 0.02$ & $0.81 \pm 0.07$ \\
\hline & $k \pm \mathrm{SE}$ & $0.13 \pm 0.01$ & $0.14 \pm 0.02$ & $0.14 \pm 0.01$ & $0.12 \pm 0.02$ \\
\hline & $t_{m} \pm \mathrm{SE}$ & $24.60 \pm 1.09$ & $19.35 \pm 1.28$ & $22.39 \pm 0.80$ & $21.84 \pm 1.96$ \\
\hline & $R^{2}$ & 0.99 & 0.98 & 0.99 & 0.97 \\
\hline \multirow[t]{4}{*}{$1 \%$} & $W_{\max } \pm \mathrm{SE}$ & $0.65 \pm 0.02$ & $0.73 \pm 0.03$ & $0.61 \pm 0.02$ & $0.81 \pm 0.05$ \\
\hline & $k \pm \mathrm{SE}$ & $0.14 \pm 0.01$ & $0.13 \pm 0.01$ & $0.16 \pm 0.01$ & $0.14 \pm 0.02$ \\
\hline & $t_{m} \pm \mathrm{SE}$ & $24.37 \pm 0.69$ & $20.10 \pm 1.21$ & $21.66 \pm 0.71$ & $20.22 \pm 1.59$ \\
\hline & $R^{2}$ & 0.99 & 0.99 & 0.99 & 0.98 \\
\hline \multirow[t]{4}{*}{$1.5 \%$} & $W_{\max } \pm \mathrm{SE}$ & $0.60 \pm 0.02$ & $0.61 \pm 0.02$ & $0.59 \pm 0.02$ & $0.78 \pm 0.05$ \\
\hline & $k \pm \mathrm{SE}$ & $0.15 \pm 0.01$ & $0.16 \pm 0.01$ & $0.16 \pm 0.01$ & $0.15 \pm 0.02$ \\
\hline & $t_{m} \pm \mathrm{SE}$ & $24.03 \pm 0.72$ & $18.73 \pm 0.70$ & $21.84 \pm 0.74$ & $19.89 \pm 1.53$ \\
\hline & $R^{2}$ & 0.99 & 0.99 & 0.99 & 0.98 \\
\hline \multirow[t]{4}{*}{$2 \%$} & $W_{\max } \pm \mathrm{SE}$ & $0.57 \pm 0.03$ & $0.61 \pm 0.02$ & $0.58 \pm 0.01$ & $0.82 \pm 0.08$ \\
\hline & $k \pm \mathrm{SE}$ & $0.13 \pm 0.01$ & $0.15 \pm 0.02$ & $0.16 \pm 0.01$ & $0.15 \pm 0.02$ \\
\hline & $t_{m} \pm \mathrm{SE}$ & $26.89 \pm 1.22$ & $19.08 \pm 0.91$ & $21.73 \pm 0.54$ & $21.49 \pm 1.48$ \\
\hline & $R^{2}$ & 0.99 & 0.99 & 0.99 & 0.98 \\
\hline \multirow[t]{4}{*}{$3 \%$} & $W_{\max } \pm \mathrm{SE}$ & $0.22 \pm 0.02$ & $0.29 \pm 0.02$ & $0.25 \pm 0.01$ & $0.33 \pm 0.02$ \\
\hline & $k \pm \mathrm{SE}$ & $0.10 \pm 0.02$ & $0.13 \pm 0.02$ & $0.14 \pm 0.01$ & $0.19 \pm 0.03$ \\
\hline & $t_{m} \pm \mathrm{SE}$ & $23.88 \pm 3.05$ & $21.46 \pm 1.52$ & $21.25 \pm 0.86$ & $20.85 \pm 1.22$ \\
\hline & $R^{2}$ & 0.96 & 0.98 & 0.99 & 0.98 \\
\hline
\end{tabular}

Estimation after 2 days of incubation as calculated by Eq. 2 (A); prediction of absorbance rate per hour during 2 days of incubation at different salinity levels of nutrient broth medium, as calculated by model Eq. 3 (B)

$\mathrm{Ab}_{\max }:$ maximum absorbance; $x_{50}$ : concentration of $\mathrm{NaCl}$ required for $50 \%$ inhibition of the maximum absorbance; $s$ : slope of the curve in $x_{50}$; $\mathrm{R}^{2}$ : coefficient of determination; $W$ : the absorbance value at time $t ; k$ : a constant that determines the curvature of the growth pattern; $t_{m}$ : the inflection point when the absorbance rate reaches the peak

According to the results, several bacterial isolates have been isolated from the durum wheat field with the remarkable capability to solubilize of insoluble inorganic $\mathrm{P}, \mathrm{K}$, and
Zn compounds and fix $\mathrm{N}_{2}$. Twelve isolates expressing some plant growth-promoting traits (i.e., $\mathrm{P}, \mathrm{K}$, and $\mathrm{Zn}$ solubilization, $\mathrm{N}_{2}$ fixation, and IAA production) at the highest levels 
Table 7 Prediction of the absorbance rate (per hour) at different temperatures of incubation, as calculated by Eq. 4 (A) and estimation of the effect of different temperatures on bacterial growth during $34 \mathrm{~h}$ of incubation, as calculated by model Eq. 3 (B)

\begin{tabular}{|c|c|c|c|c|c|}
\hline Parameters & & KSB isolate (CT21) & PSB isolate (NT28) & ZSB isolate (NT10) & NFB isolate (NT3) \\
\hline \multicolumn{6}{|l|}{ (A) } \\
\hline$T_{\mathrm{o}} \pm \mathrm{SE}$ & & $24.56 \pm 1.71$ & $28.25 \pm 0.91$ & $27.41 \pm 1.32$ & $23.28 \pm 1.88$ \\
\hline$T_{\mathrm{b}} \pm \mathrm{SE}$ & & $2.82 \pm 0.22$ & $2.02 \pm 0.14$ & $2.32 \pm 0.19$ & $2.06 \pm 0.24$ \\
\hline$T_{\mathrm{c}} \pm \mathrm{SE}$ & & $45.12 \pm 1.11$ & $44.56 \pm 0.00$ & $46.05 \pm 1.13$ & $42.18 \pm 1.83$ \\
\hline$R^{2}$ & & 0.95 & 0.97 & 0.92 & 0.95 \\
\hline Temperatures & Parameters & & & & \\
\hline \multicolumn{6}{|l|}{ (B) } \\
\hline \multirow[t]{4}{*}{$4{ }^{\circ} \mathrm{C}$} & $W_{\max } \pm \mathrm{SE}$ & $0.14 \pm 0.04$ & $0.11 \pm 0.01$ & $0.10 \pm 0.01$ & $0.13 \pm 0.06$ \\
\hline & $k \pm \mathrm{SE}$ & $0.12 \pm 0.02$ & $0.14 \pm 0.04$ & $0.15 \pm 0.03$ & $0.10 \pm 0.03$ \\
\hline & $t_{m} \pm \mathrm{SE}$ & $26.25 \pm 5.41$ & $17.88 \pm 2.91$ & $22.89 \pm 2.27$ & $26.49 \pm 9.79$ \\
\hline & $R^{2}$ & 0.99 & 0.95 & 0.98 & 0.94 \\
\hline \multirow[t]{4}{*}{$18^{\circ} \mathrm{C}$} & $W_{\max } \pm \mathrm{SE}$ & $0.52 \pm 0.01$ & $0.72 \pm 0.07$ & $0.55 \pm 0.02$ & $0.64 \pm 0.02$ \\
\hline & $k \pm \mathrm{SE}$ & $0.29 \pm 0.02$ & $0.18 \pm 0.04$ & $0.23 \pm 0.02$ & $0.28 \pm 0.03$ \\
\hline & $t_{m} \pm \mathrm{SE}$ & $19.07 \pm 0.33$ & $19.50 \pm 1.63$ & $18.39 \pm 0.47$ & $16.83 \pm 0.50$ \\
\hline & $R^{2}$ & 0.99 & 0.97 & 0.99 & 0.99 \\
\hline \multirow[t]{4}{*}{$30^{\circ} \mathrm{C}$} & $W_{\max } \pm \mathrm{SE}$ & $0.49 \pm 0.05$ & $0.58 \pm 0.01$ & $0.45 \pm 0.01$ & $0.51 \pm 0.02$ \\
\hline & $k \pm \mathrm{SE}$ & $0.15 \pm 0.04$ & $0.26 \pm 0.02$ & $0.25 \pm 0.03$ & $0.18 \pm 0.02$ \\
\hline & $t_{m} \pm \mathrm{SE}$ & $16.59 \pm 2.22$ & $12.14 \pm 0.55$ & $12.38 \pm 0.51$ & $13.66 \pm 0.86$ \\
\hline & $R^{2}$ & 0.96 & 0.99 & 0.99 & 0.99 \\
\hline \multirow[t]{4}{*}{$40^{\circ} \mathrm{C}$} & $W_{\max } \pm \mathrm{SE}$ & $0.45 \pm 0.08$ & $0.62 \pm 0.07$ & $0.40 \pm 0.01$ & $0.18 \pm 0.01$ \\
\hline & $k \pm \mathrm{SE}$ & $0.16 \pm 0.04$ & $0.18 \pm 0.05$ & $0.26 \pm 0.03$ & $0.20 \pm 0.02$ \\
\hline & $t_{m} \pm \mathrm{SE}$ & $23.83 \pm 3.05$ & $20.62 \pm 2.04$ & $17.01 \pm 0.53$ & $18.53 \pm 0.84$ \\
\hline & $R^{2}$ & 0.97 & 0.96 & 0.99 & 0.99 \\
\hline
\end{tabular}

$T:$ the temperature; $T_{\mathrm{b}}$ : the base temperature; $T_{\mathrm{o}}$ : the optimum temperature; $T_{\mathrm{c}}$ : the ceiling temperature; $\mathrm{R}^{2}$ : coefficient of determination; $W:$ the absorbance value at time $t(34 \mathrm{~h}) ; k$ : a constant that determines the curvature of the growth pattern; $t_{m}$ : the inflection point when the absorbance rate reaches the peak which is half of its maximum value $\left(w_{\max }\right)$

were further characterized in liquid mediums and identified. Our PSB and KSB isolates identified as Acinetobacter pittii, Pseudomonas alcaligenes, Acinetobacter calcoaceticus, Acinetobacter sp., and Acinetobacter oleivorans. Although bacteria belonging to Pseudomonas have been already reported to include PSB and KSB as well as Acinetobacter which is known as PSB [27-29], to our knowledge, this is the first report on K solubilization potential of genera Acinetobacter.

A high regression coefficient was observed between the reduction in $\mathrm{pH}_{\mathrm{f}}$ and increscent capacity to solubilize $\mathrm{P}$ in liquid medium after 14 days of incubation. All the $\mathrm{pH}_{\mathrm{m}}$ of cultures showed a shift in $\mathrm{pH}_{\mathrm{f}}$ towards the acidic range, and this can give a clue that organic acid exudation might be involved in $\mathrm{P}$ solubilizing at all $\mathrm{pH}_{\mathrm{m}}$. Accordingly, the PSB strain (NT28) was a more efficient phosphate solubilizer at $\mathrm{pH}_{\mathrm{m}} 8$ than at other $\mathrm{pH}_{\mathrm{m}}$, while the lowest $\mathrm{pH}_{\mathrm{f}}$ was obtained from $\mathrm{pH}_{\mathrm{m}}$ 7. These findings are inconsistent with other studies, such as Bakhshandeh et al. [6] for Pantoea ananatis, Rahnella aquatilis, and Enterobacter sp., who reported that the highest levels of $\mathrm{P}$ solublilizing activity were observed at the optimum $\mathrm{pH}$ (7.0). A possible explanation is that this strain was isolated from a soil with a quite high $\mathrm{pH}(7.5)$, a common situation for soils from southern Italy whose $\mathrm{pH}$ are often about 8 [30].

The K solubilizing activity was observed at $\mathrm{pH}_{\mathrm{m}}$ of 7-9, equal to $35.6,8$, and $6 \mu \mathrm{g} \mathrm{ml}^{-1}$ along with $\mathrm{pH}_{\mathrm{f}}$ of $4.3,5.4$ and 5.7, respectively. In fact, more activity of KSB strain resulted in a further decrease in $\mathrm{pH}_{\mathrm{f}}$ and consequently, more $\mathrm{K}$ releasing from mica compound. Similar to the PSB strategy, it may be related to releasing organic acids in the medium by KSB strain, Acinetobacter oleivorans. Such results are confirmed by Bakhshandeh et al. [19] and Yaghoubi et al. [11] who stated that the various types of organic acids produced due to the metabolism of KSB isolates which can affect mica dissolution by decreasing the $\mathrm{pH}$ of the environment, forming frame work-destabilizing surface complexes or by complexing metals in solution. Likewise, polysaccharides can attach to the mineral surface by adsorbing the organic acids and consequently can increase the organic acids concentration near the mineral [31].

The four ZSB isolates in this research were identified as Acinetobacter calcoaceticus, Pseudomonas alcaligenes, and Pseudomonas sp. It has also been reported that the majority 
of ZSB belongs to Pseudomonas, Acinetobacter, Bacillus, Enterobacter, Xanthomonas, and Stenotrophomonas genera [18, 32]. The ability of ZSB isolates including Pseudomonas sp. and Bacillus sp. was assessed by Saravanan et al. [33] who reported a maximum $\mathrm{Zn}$ solubilization equal to $16.4 \mu \mathrm{g} \mathrm{g}^{-1}$ of $\mathrm{Zn}$ in the $\mathrm{ZnO}$. Similarly, Zn-solubilizing potentiality of $143 \mathrm{ZSB}$ isolates was assessed by Gandhi and Muralidharan [18] and reported the maximum ZSB activity by Acinetobacter sp. equal to $36.5 \mu \mathrm{g} \mathrm{Zn} \mathrm{ml}{ }^{-}$of medium amended by $\mathrm{ZnO}$.

Since soil $\mathrm{pH}$ is a relevant factor affecting the colonization, abundance, and prevalence of PGPB in the soil [25], attempt was made to investigate the effect of different $\mathrm{pH}$ values of the medium $\left(\mathrm{pH}_{\mathrm{m}}\right)$ on beneficial bacterial activity in vitro. In this regard, the responses of bacterial strains to different $\mathrm{pH}_{\mathrm{m}}$ values were different. For instance, the highest $\mathrm{Zn}$ solubilizing activity was found at $\mathrm{pH}_{\mathrm{m}} 8-10$, while no solubilization was observed at $\mathrm{pH}_{\mathrm{m}}$ of 6 and 7. On the other hand, as above discussed, the maximum solubilization of $\mathrm{K}$ and $\mathrm{P}$ occurred at $\mathrm{pH}_{\mathrm{m}} 7$ and 8, respectively. A similar finding for ZSB has been reported in our previous research; accordingly, the highest $\mathrm{ZSB}$ activity was observed at $\mathrm{pH}_{\mathrm{m}}$ 9, which was significantly higher than that at other $\mathrm{pH}$ [13]. It has already reported that some PGPB are able to mobilize mineral nutrients even at $\mathrm{pH} 12$ through a variety of mechanisms such as production of bacterial metabolites [34]. In this regard, Mimmo et al. [35] reported that mobilization of mineral nutrients like $\mathrm{Zn}$ by low-molecular weight organic acids, phenolics, and siderophores is mainly caused by the complexing capacity of these molecules rather than their acidity. This complexing capacity is increased at higher $\mathrm{pH}$ because deprotonated carboxilic and phenolic moieties are better Lewis bases to react with metal cations (Lewis acids). It has also been stated that organic compounds with more than one acidic moiety (e.g., citric acid) have a stronger complexing capacity at higher $\mathrm{pH}$. when all the acidic functional groups are successively deprotonated thus allowing the formation of polydentate complexes with cations possessing more than one positive charge like $\mathrm{Fe}^{3+}$ and $\mathrm{Zn}^{++}$ [35].

Therefore, our bacterial strains could be beneficial to use as bio-inoculants on agricultural land with high $\mathrm{pH}$ values, since high $\mathrm{pH}$ is one of the most important factors contributing to the unavailability of $\mathrm{Zn}$ in soils [36]. Furthermore, insoluble $\mathrm{Zn}$ compounds such as $\mathrm{Zn}(\mathrm{OH})_{2}$ and $\mathrm{ZnCO}_{3}$ usually form from soluble $\mathrm{Zn}$ compound and $\mathrm{Zn}$ chemical fertilizer at $\mathrm{pH}$ of 7.7-9.1 [32], which can result in unavailability of $\mathrm{Zn}$ in soils and $\mathrm{Zn}$ deficiency symptoms in plants, especially on calcareous soils in southern Italy $(\mathrm{pH}>8)$.

In the present research, $\mathrm{N}_{2}$ fixation activity in liquid medium was observed from $19.2 \mu \mathrm{g} \mathrm{ml}^{-1}$ (Pseudomonas sp., strain NT2 with $123 \%$ of N fixation efficiency) to $25.2 \mu \mathrm{g} \mathrm{ml}^{-1}$ (Comamonas testosteroni, strain NT3 with
$136 \%$ of $\mathrm{N}$ fixation efficiency). It has been already proved that Pseudomonas genusis one of the most important of NFB genera [37], but no studies have been reported that the Comamonas genusis capable to fix on $\mathrm{N}_{2}$.

The final $\mathrm{pH}$ of the medium after the incubation period slightly decreased for NT3 strain, Comamonas testosteroni, while inversely the $\mathrm{pH}_{\mathrm{f}}$ for other NFB strains, Pseudomonas sp., increased. NFB bacteria convert the atmospheric $\mathrm{N}_{2}$ into ammonia $\left(\mathrm{NH}_{3}\right)$ as a plant-utilizable form [10]. This process is an $\mathrm{H}^{+}$consumer and subsequently leads to change the $\mathrm{pH}$. It has in fact reported that increasing the $\mathrm{pH}$ of the rhizospheric soil may be an important consequence of $\mathrm{N}_{2}$ fixation by bacteria [38]. On the other hand, Oliveira et al. [39] examined five NFB bacterial strains and reported the $\mathrm{pH}$ of the culture medium after growth for four strains was neutral while another strain changed the $\mathrm{pH}$ to acidic.

The differences in $\mathrm{pH}_{\mathrm{f}}$ among isolates may be related to the different $\mathrm{N}_{2}$ fixing systems. Similarly, Ahemad and Kibert [40] stated that $\mathrm{N}_{2}$ fixing system varies among different bacterial genera. It has been reported that the $\mathrm{N}_{2}$ fixation process is carried out by the nitrogenase complex enzyme, including a dinitrogenase reductase and dinitrogenase [41]. Dinitrogenase reductase provides electrons with high reducing power while dinitrogenase uses these electrons to reduce $\mathrm{N}_{2}$ to $\mathrm{NH}_{3}$ [40]. According to the metal cofactor, three different $\mathrm{N}$ fixing systems have been recognized including Monitrogenase, V-nitrogenase, and Fe-nitrogenase [41]. Most biological $\mathrm{N}_{2}$ fixation is carried out by the activity of the Mo-nitrogenase [40].

Since the bacteria survival during growth depends on their ability to adapt to the varying environmental conditions such as temperature and salt stress [6]; in this study, an attempt was made to optimize the growth conditions of selected beneficial bacteria at different $\mathrm{NaCl}$ concentrations (\%) and temperatures. However, the finding of the present research showed that the selected bacteria were able to grow on $\mathrm{NB}$ medium amended with $0.5-3 \% \mathrm{NaCl}$ at a range of examined temperatures from 4 to $40^{\circ} \mathrm{C}$, but modeling analyses estimated optimal growth conditions for possible practical applications. In this regard, the best growth conditions for Acinetobacter oleivorans (KSB strain), Acinetobacter pittii (PSB strain), and Acinetobacter calcoaceticus (ZSB strain) were obtained at $0.67,0.74$, and $0.64 \%$ of $\mathrm{NaCl}$ concentration, at $24.6,28.2$, and $27.4{ }^{\circ} \mathrm{C}$ and in $\mathrm{pH} 7,8$, and 9 , respectively. Conditions for Comamonas testosteroni (NFB strain) were a bit more different from other strains. Accordingly, the best growth for NFB strain was estimated at higher $\mathrm{NaCl}$ concentration $(0.92 \%)$ and lower temperature $\left(23.3{ }^{\circ} \mathrm{C}\right.$,) than other bacterial strains. Complete inhibition of growth was estimated from $3.5 \% \mathrm{NaCl}$ for PSB strain to $9.3 \% \mathrm{NaCl}$ for NFB strain. Application of these bacterial strains with great potential of growth and activity in such wide ranges of $\mathrm{pH}$, salinity levels, and temperatures could 
be useful in soil inoculation, since it is important to maintain high microbial activity in soils $[6,42]$, where microorganisms are continually challenged by environmental fluctuations [43]. It has already been reported that microbial growth and activity decreased under saline conditions, due to two primary mechanisms including osmotic effect and specific ion effects [42]. The previous study has shown that the complete inhibitions of Agrobacterium tumefaciens and Rhizobium sp. growth in NB medium were estimated at 4.3 and $6.6 \% \mathrm{NaCl}$, respectively [13]. The optimum $\mathrm{NaCl}$ concentration for the majority of bacterial isolates was reported at $0.5 \% \mathrm{NaCl}$ [6]. Bakhshandeh et al. [6] reported that three PSB including Pantoea ananatis, Rahnella aquatilis, and Enterobacter sp. were tolerant to a range of temperature from 5 to $42.7^{\circ} \mathrm{C}, 12.7-40{ }^{\circ} \mathrm{C}$, and $10.6-43.3$ (with optimum $30,31.4$, and $30^{\circ} \mathrm{C}$ ), respectively. It has also reported that the optimal temperature for $\mathrm{N}_{2}$ fixation by $B$. japonicum ranges from 25 to $30^{\circ} \mathrm{C}$ and temperatures over or below this range are inhibitory [14].

The analysis of bacterial community composition and $\alpha$ diversity are fully discussed in Yaghoubi et al. [44]. Briefly, soils under NT management had more copiotrophic bacteria including Proteobacteria, Bacteroidetes, and Planctomycetes, which are known for their high sensitivity to physical soil disturbance $[45,46]$. Species richness and bacterial diversity, as estimated by Chao1 and Shannon index, respectively, were higher in soils under NT treatment as compared to the CT practice. This finding is in agreement to others, such as Schmidt et al. [47] and Hao et al. [48] who reported a decreasing trend of the microbial community richness and diversity in soil under CT practice, due to a reduced substrate richness.

We analyzed the presence of the taxonomic groups our potentially beneficial bacterial strains belonged to, in order to know if tillage/no-tillage management affects their presence in soil, even if it should be considered that, these taxa can also include bacteria without such beneficial abilities. Based on the analysis of the taxonomic composition, our bacterial strains belonged to the Proteobacteria phylum and Moraxellaceae, Pseudomonadaceae, and Comamonadaceae families which are known as copiotrophic taxa, based on their life strategies in response to resource availability [49] and soil management, especially physical soil disturbance by tillage [46]. It seems that the reduction of soil disturbance through NT technique can lead to an increase in the content of soil carbon availability [47] and consequently, results in the higher presence of these phylum and families [26] as compared to the CT. Therefore, we can reasonably assume that the preservation of an agro-ecosystem under no disturbance can boost the presence of these beneficial bacterial strains in soil in comparison with the CT management. Similarly, Dong et al. [28] evidenced that the abundance and diversity of KSB decreased after agricultural activities.
Souza et al. [50] also reported that the relative abundance of a PGPB order (Rhizobiales) increased under NT practice. A recent study emphasized that the importance of the effect of tillage regime on soil physical and chemical conditions that in turn influence the abundance of beneficial microorganisms [51].

\section{Conclusion}

The present research reveals that some effective bacterial strains including Pseudomonas, Acinetobacter, and Comamonas genera, isolated and identified from the durum wheat field, have such a great potential to solubilize the insoluble forms of phosphate, potassium, and zinc as well as to fix $\mathrm{N}_{2}$ gas. To our knowledge, this is the first report of the ability of Comamonas testosteroni and Acinetobacter pittii to fix nitrogen and to solubilize insoluble potassium compound, respectively. A detailed assessment of the tolerance of beneficial bacterial strains to salt stress threshold and different temperatures are presented in this research using mathematical models. So, these strains could be definitively recommended as inoculants to promote plant growth in an agricultural environment in the wide ranges of $\mathrm{pH}$, salinity levels, and temperatures, but more in-depth studies will be needed to confirm these solubilizing and fixing activities.

Acknowledgements The authors thank Dr. Maddalena Curci and Dr. Esmaeil Bakhshandeh for their technical and modeling analysis assistance, respectively. TXRF analysis was led at the "Micro X-ray Lab" of the University of Bari (Italy).

Author Contributions Conceptualization: [MYK, CC]; Methodology: [MYK, CC]; Formal analysis and investigation: [MYK, SS, IA]; Writing-original draft preparation: [MYK, CC]; Writing—review and editing: [MYK, CC]; Funding acquisition: [CC]; Supervision: [CC].

Funding Open access funding provided by Università degli Studi di Bari Aldo Moro within the CRUI-CARE Agreement.

\section{Compliance with Ethical Standards}

Conflict of interest The authors declare that they have no conflict of interest.

Open Access This article is licensed under a Creative Commons Attribution 4.0 International License, which permits use, sharing, adaptation, distribution and reproduction in any medium or format, as long as you give appropriate credit to the original author(s) and the source, provide a link to the Creative Commons licence, and indicate if changes were made. The images or other third party material in this article are included in the article's Creative Commons licence, unless indicated otherwise in a credit line to the material. If material is not included in the article's Creative Commons licence and your intended use is not permitted by statutory regulation or exceeds the permitted use, you will need to obtain permission directly from the copyright holder. To view a copy of this licence, visit http://creativecommons.org/licenses/by/4.0/. 


\section{References}

1. Duncan EG, O’Sullivan CA, Roper MM, Biggs JS, Peoples MB (2018) Influence of co-application of nitrogen with phosphorus, potassium and sulphur on the apparent efficiency of nitrogen fertiliser use, grain yield and protein content of wheat: review. Field Crop Res 226:56-65

2. Paulsen GM, Shroyer JP, Shroyer KJ (2016) Wheat: agronomy. Encycl Food Grains 4:176-185. https://doi.org/10.1016/B978-012-394437-5.00200-X

3. ISTAT (2018) http://www.istat.it/en/. Last access, March 2016

4. Rengel Z (2015) Availability of $\mathrm{Mn}, \mathrm{Zn}$ and $\mathrm{Fe}$ in the rhizosphere. J Soil Sci Plant Nutr 15(2):397-409

5. Adesemoye AO, Kloepper JW (2009) Plant-microbes interactions in enhanced fertilizer-use efficiency. Appl Microbiol Biotechnol $85: 1-12$

6. Bakhshandeh E, Rahimian H, Pirdashti H, Nematzadeh G (2014) Phosphate solubilization potential and modeling of stress tolerance of rhizobacteria from rice paddy soil in northern Iran. World J Microbiol Biotechnol 30:2437-2447. https:// doi.org/10.1007/s11274-014-1669-1

7. Yaghoubi Khanghahi M, Pirdashti H, Rahimian H, Nematzadeh GA, Ghajar Sepanlou M (2018a) Nutrient use efficiency and nutrient uptake promoting of rice by potassium solubilizing bacteria (KSB). Cereal Res Commun 46(4):739-750. https:// doi.org/10.1556/0806.46.2018.042

8. Pii Y, Borruso L, Brusetti L, Crecchio C, Cesco S, Mimmo $\mathrm{T}$ (2016) The interaction between iron nutrition, plant species and soil type shapes the rhizosphere microbiome. Plant Physiol Biochem 99:39-48

9. Ramakrishna W, Yadav R, Li K (2019) Plant growth promoting bacteria in agriculture: two sides of a coin. Appl Soil Ecol 138:10-18. https://doi.org/10.1016/j.apsoil.2019.02.019

10. Pii Y, Mimmo T, Tomasi N, Terzano R, Cesco S, Crecchio C (2015) Microbial interactions in the rhizosphere: beneficial influences of plant growth promoting rhizobacteria on nutrient acquisition process. A review. Biol Fertil Soils 51:403-415

11. Yaghoubi Khanghahi M, Pirdashti H, Rahimian H, Nematzadeh GA, Ghajar Sepanlou M (2018b) Potassium solubilising bacteria (KSB) isolated from rice paddy soil: from isolation, identification to K use efficiency. Symbiosis 76:13-23

12. Scagliola M, Pii Y, Mimmo T, Cesco S, Ricciuti P, Crecchio C (2016) Characterization of plant growth promoting traits of bacterial isolates from the rhizosphere of barley (Hordeum vulgare L.) and tomato (Solanum lycopersicon L.) grown under Fe sufficiency and deficiency. Plant Physiol Biochem 107:187-196

13. Yaghoubi Khanghahi M, Ricciuti P, Allegretta I, Terzano R, Crecchio C (2018) Solubilization of insoluble zinc compounds by zinc solubilizing bacteria (ZSB) and optimization of their growth conditions. Environ Sci Pollut Res 25:25862-25868

14. Torabian Sh, Farhangi-Abriz S, Denton MD (2019) Do tillage systems influence nitrogen fixation in legumes? A review. Soil Tillage Res 185:113-121

15. Dobereiner $\mathbf{J}$ (1988) Isolation and identification of root associated diazotrophs. Plant Soil 110:207-212

16. Pikovskaya R (1948) Mobilization of phosphorus in soil in connection with vital activity of some microbial species. Mikrobiologiya 17:362-370

17. Aleksandrov VG, Blagodyr RN, Live IP (1967) Liberation of phosphoric acid from apatite by silicate bacteria. Microchem J 29:111-114

18. Gandhi A, Muralidharan G (2016) Assessment of zinc solubilizing potentiality of Acinetobacter sp. isolated from rice rhizosphere. Eur J Soil Biol 76:1-8
19. Bakhshandeh E, Pirdashti H, Shahsavarpour Lendeh K (2017) Phosphate and potassium-solubilizing bacteria effect on the growth of rice. Ecol Eng 103:164-169

20. Gordon SA, Weber RP (1951) Colorimetric estimation of indole acetic acid. Plant Physiol 26(1):192-195

21. Yu Z, Morrison M (2004) Comparisons of different hyper variable regions of rrs genes for use in fingerprinting of microbial communities by PCR-denaturing gradient gel electrophoresis. Appl Environ Microbiol 70(8):4800-4806

22. Kuczynski J, Stombaugh J, Walters WA, González A, Caporaso JG, Knight R (2011) Using QIIME to analyze 16S rRNA gene sequences from microbial communities. Curr Protoc Bioinform 36:10.7.1-10.7.20

23. Yin X, Gouadrian J, Latinga EA, Vos J, Spiertz JH (2003) A flexible sigmoid growth function of determinate growth. Ann Bot 91:361-371

24. Yan W, Hunt LA (1999) An equation for modelling the temperate response of plants using only the cardinal temperatures. Ann Bot 84:607-614

25. Rilling JJ, Acuña JA, Nannipieri P, Cassan F, Maruyama F, Jorquera MA (2018) Current opinion and perspectives on the methods for tracking and monitoring plant growth-promoting bacteria. Soil Biol Biochem. https://doi.org/10.1016/j.soilb io.2018.12.012

26. Yaghoubi Khanghahi M, Murgese P, Strafella S, Crecchio C (2019) Soil biological fertility and bacterial community response to land use intensity: a case study in the Mediterranean area. Diversity 11:211

27. Arora NK, Fatima T, Mishra I, Verma S (2020) Microbebased inoculants: role in next green revolution. In: Shukla $\mathrm{V}$, Kumar N (eds) Environmental concerns and sustainable development. Springer, Singapore. https://doi. org/10.1007/978-981-13-6358-0_9

28. Dong X, Lv L, Wang W, Liu Y, Yin C, Xu Q, Yan H, Fu J, Liu X (2019) Differences in distribution of potassium-solubilizing bacteria in forest and plantation soils in Myanmar. Int J Environ Res Public Health 16(5):700

29. Kour D, Rana KL, Kaur T, Sheikh I, Yadav AN, Kumar V, Dhaliwal HS, Saxena AK (2020) Microbe-mediated alleviation of drought stress and acquisition of phosphorus in great millet (Sorghum bicolour L.) by drought-adaptive and phosphorus-solubilizing microbes. Biocatal Agric Biotechnol 23:101501

30. Sequi P, Ciavatta C, Miano T (2017) Fondamenti di chimica del suolo. Pàtron editore S.r.l. pp 296

31. Liu W, Xu X, Wu S, Yang Q, Luo Y, Christie P (2006) Decomposition of silicate minerals by Bacillus mucilaginosus in liquid culture. Environ Geochem Health 28:133-140

32. Sunithakumari K, Padma Devi SN, Vasandha S (2016) Zinc solubilizing bacterial isolates from the agricultural fields of Coimbatore, Tamil Nadu, India. Curr Sci 110(2):196-205

33. Saravanan VS, Subramoniam SR, Raj SA (2003) Assessing in vitro solubilization potential of different zinc solubilizing bacteria (ZSB) isolates. Braz J Microbiol 34:121-125

34. Nautiyal CS, Bhaduriya S, Kumar P, Lal HC, Mondal R, Verma D (2000) Stress induced phosphate solubilization in bacteria isolated in alkaline soils. FEMS Microbiol Lett 182:291-296

35. Mimmo T, Del Buono D, Terzano R, Tomasi N, Vigani G, Crecchio C, Pinton R, Zocchi G, Cesco S (2014) Rhizospheric organic compounds in the soil-microorganism-plant system: their role in iron availability. Eur J Soil Sci 65:629-642

36. Laurent C, Bravin MN, Crouzet O, Pelosi C, Tillard E, Lecomte P, Lamy I (2020) Increased soil pH and dissolved organic matter after a decade of organic fertilizer application mitigates copper and zinc availability despite contamination. Sci Total Environ 709:135927 
37. Fang K, Bao ZS, Chen L, Zhou J, Ping Z (2019) Growth-promoting characteristics of potential nitrogen-fixing bacteria in the root of an invasive plant Ageratina adenophora. PeerJ 7:e7099

38. Perez-Galdona R, Kahn ML (1994) Effects of organic acids and low $\mathrm{pH}$ on Rhizobium meliloti 104A14. Microbiology 140:1231-1235

39. Oliveira DP, de Figueiredo MA, Soares BL, Teixeira OHS, Martins FAD, Rufini M, Chain CP, Reis RP, de Morais AR, de Souza Moreira FM, de Andrade MJB (2017) Acid tolerant Rhizobium strains contribute to increasing the yield and profitability of common bean in tropical soils. J Soil Sci Plant Nutr 17(4):922-934

40. Ahemad M, Kibret M (2014) Mechanisms and applications of plant growth promoting rhizobacteria: current perspective. J King Saud Univ Sci 26:1-20

41. Hoffman BM, Lukoyanov D, Yong ZY, Dean DR, Seefeldt LC (2014) Mechanism of nitrogen fixation by nitrogenase: the next stage. Chem Rev 114:4041-4062

42. Yan N, Marschner P, Cao W, Zuo Ch, Qin W (2015) Influence of salinity and water content on soil microorganisms. Int Soil Water Conserv Res 3(4):316-323

43. Giordano N (2018) Microbial growth control in changing environments: theoretical and experimental study of resource allocation in Escherichia coli. PhD thesis, Université Grenoble Alpes, p 202. https://tel.archives-ouvertes.fr/tel-01685626/document

44. Yaghoubi Khanghahi M, Cucci G, Lacolla G, Lanzellotti L, Crecchio C (2020) Soil fertility and bacterial community composition in a semiarid Mediterranean agricultural soil under long-term tillage management. Soil Use Manag. https://doi.org/10.1111/ sum. 12645
45. Lienhard P, Terrat S, Prevost-Boure NC, Nowak V, Regnier T, Sayphoummie S, Panyasiri K, Tivet F, Mathieu O, Leveque J, Maron PA, Ranjard L (2014) Pyrosequencing evidences the impact of cropping on soil bacterial and fungal diversity in Laos tropical grassland. Agron Sustain Dev 34:525-533

46. Babin D, Deubel A, Jacquiod S, Sorensen SJ, Geistlinger J, Grosch R, Smalla K (2019) Impact of long-term agricultural management practices on soil prokaryotic communities. Soil Biol Biochem 129:17-28

47. Schmidt MP, Martínez CE (2019) The influence of tillage on dissolved organic matter dynamics in a Mid-Atlantic agroecosystem. Geoderma 344:63-73

48. Hao M, Hu H, Liu Z, Dong Q, Sun K, Feng Y, Li G, Ning T (2019) Shifts in microbial community and carbon sequestration in farmland soil under long-term conservation tillage and straw returning. Appl Soil Ecol 136:43-54

49. Lladó S, Baldrian P (2017) Community-level physiological profiling analyses show potential to identify the copiotrophic bacteria present in soil environments. PLoS One 12:e0171638

50. Souza RC, Cantão ME, Vasconcelos ATR, Nogueira MA, Hungria M (2013) Soil metagenomics reveals differences under conventional and no-tillage with crop rotation or succession. Appl Soil Ecol 72:49-61

51. Degrune F, Theodorakopoulos N, Colinet G, Hiel M, Bodson B, Taminiau B, Daube G, Vandenbol M, Hartmann M (2017) Temporal dynamics of soil microbial communities below the seedbed under two contrasting tillage regimes. Front Microbiol 8:1127

Publisher's Note Springer Nature remains neutral with regard to jurisdictional claims in published maps and institutional affiliations. 